\title{
Non-pharmaceutical behavioural measures for droplet-borne biological hazards prevention: Health-EDRM for COVID-19 (SARS-CoV-2) Pandemic
}

Emily Ying Yang Chan ${ }^{1-4}$, Tayyab Salim Shahzada ${ }^{3,4}$, Tiffany Sze Tung Sham ${ }^{3,4}$, Caroline Dubois ${ }^{4}$, Zhe Huang ${ }^{1,3}$, Sida Liu ${ }^{1,4}$, Janice Ying-en $\mathrm{Ho}^{1,3}$, Kevin KC Hung ${ }^{1,3,5}$, Kwok Kin On ${ }^{3}$, Ryoma $\mathrm{Kayano}^{6}$, Rajib Shaw7.

\footnotetext{
${ }^{I}$ Collaborating Centre for Oxford University and CUHK for Disaster and Medical Humanitarian Response (CCOUC), The Chinese University of Hong Kong, Hong Kong, China

${ }^{2}$ Nuffield Department of Medicine, University of Oxford, Oxford OX37BN, UK

${ }^{3}$ JC School of Public Health and Primary Care, Faculty of Medicine, The Chinese University of Hong Kong, Hong Kong, China

${ }^{4}$ GX Foundation, Hong Kong, China

${ }^{5}$ Accident \& Emergency Medicine Academic Unit, The Chinese University of Hong Kong, Prince of Wales Hospital, Hong Kong SAR, China

${ }^{6}$ WHO Centre for Health Development, Kobe, Japan

${ }^{7}$ Keio University, Japan
}

\section{Corresponding Author:}

Professor Emily Ying Yang Chan

emily.chan@cuhk.edu.hk

$+85222528850$

Rm 308, 3/F, JC School of Public Health, Prince of Wales Hospital, Shatin, Hong Kong SAR

Short title: Non-pharmaceutical H-EDRM Measures for COVID-19

\begin{abstract}
(143 words)
Introduction: Non-pharmaceutical interventions to facilitate response to the COVID-19 pandemic, a disease caused by novel coronavirus SARS-CoV-2, are urgently needed. Using the WHO health emergency and disaster risk management (health-EDRM) framework, behavioural measures for droplet-borne communicable disease, with their enabling and limiting factors at various implementation levels were evaluated.

Sources of data: Keyword search was conducted in PubMed, Google Scholar, Embase, Medline, Science Direct, WHO and CDC online publication database. Using OCEBM as review criteria, 105 English-language articles, with ten bottom-up, non-pharmaceutical prevention measures, published between January 2000 and May 2020 were identified and examined.

Areas of Agreement: Evidence-guided behavioural measures against COVID-19 transmission for global at-risk communities are identified.

Area of Concern: Strong evidence-based systematic behavioural studies for COVID-19 prevention are lacking.

Growing points: Very limited research publications are available for non-pharmaceutical interventions to facilitate pandemic response.
\end{abstract}


medRxiv preprint doi: https://doi.org/10.1101/2020.05.29.20116475; this version posted May 29, 2020. The copyright holder for this preprint (which was not certified by peer review) is the author/funder, who has granted medRxiv a license to display the preprint in perpetuity. It is made available under a CC-BY-NC-ND 4.0 International license .

Areas timely for research: Research with strong implementation feasibility that targets resource-poor settings with low baseline Health-EDRM capacity is urgently need.

Keywords: Health-EDRM, behavioural measures, non-pharmaceutical, primary prevention, droplet-borne, biological hazards, COVID-19, SARS-CoV-2, coronavirus, pandemic

\section{Introduction}

Uncertainties in disease epidemiology, treatment and management in biological hazards have often urged policy makers and community health protection to revisit prevention approaches to maximise infection control and protection. The COVID-19 pandemic, a disease caused by novel coronavirus SARS-CoV-2, has pushed global governments and communities to revisit the appropriate non-pharmaceutical, health prevention measures in response to this unexpected virus outbreak $^{1}$. The World Health Organisation (WHO) health emergency and disaster risk management (health-EDRM) framework refers to the structured analysis and management of health risks brought upon by emergencies and disasters. The framework focuses on prevention and risk mitigation through hazard and vulnerability reduction, preparedness, response and recovery measures ${ }^{2}$, and further calls attention to the significance of community involvement to counteract the potential negative impacts of hazardous events such as infectious disease outbreaks $^{2}$. COVID-19 is defined as a biological hazard under the health-EDRM disaster classification $^{3}$. While there is evidence for potential COVID-19 droplet transmission ${ }^{4}$, the WHO has suggested that airborne transmission may only be possible in certain circumstances ${ }^{4}$. Further evidence is needed to categorise it as an airborne disease specifically, per the framework.

Health-EDRM prevention measures can be classified into primary, secondary or tertiary levels ${ }^{5}$. Primary prevention mitigates the occurrence of illness through an emphasis on health promotion and education aimed at behavioural modification ${ }^{6}$; secondary prevention involves screening and infection identification; and tertiary prevention focuses on treatment. In the context of COVID19 , both secondary and tertiary preventive measures are complicated due to the high incidence of asymptomatic patients ${ }^{7}$; the lack of consensus and availability of specific treatment or vaccine ${ }^{8}$; and the added stress on the health system during a pandemic. Primary prevention that focuses on protecting an individual from contracting an infection ${ }^{9}$ is thus the most practical option. A comprehensive disaster management cycle (prevention, mitigation, preparedness, response and recovery) encompasses both top-down and bottom-up measures ${ }^{10,11}$. Top-down measures require well-driven bottom-up initiatives to successfully achieve primary prevention and effectively modify community behaviours ${ }^{12}$.

Based on the health-EDRM framework, which emphases the impact of context on efficacy of measure practices ${ }^{3}$, this paper examines available published evidence on primary prevention measures that might be adopted at the personal, household and community level for droplet- 
medRxiv preprint doi: https://doi.org/10.1101/2020.05.29.20116475; this version posted May 29, 2020. The copyright holder for this preprint (which was not certified by peer review) is the author/funder, who has granted medRxiv a license to display the preprint in perpetuity. It is made available under a CC-BY-NC-ND 4.0 International license .

borne transmitted diseases, and enabling and limiting factors for each measure. Additionally, this paper reviews the strength of available scientific evidence for each of the behavioural changes measure which may reduce health risks.

\section{Methodology}

A literature search was conducted in May 2020. English-language based, international peerreviewed articles, online reports, electronic books and press releases published between January 2000 and May 2020 were identified. The snowballing search methodology was also utilised. Research databases examined in this study included PubMed, Google Scholar, Embase, Medline and Science Direct. WHO, United States Centers for Disease Control and Prevention (CDC) and other local-government publications and information outlets were also included. The following keywords or phrases were searched for: 'health-EDRM'. 'COVID-19' 'risk-management', 'droplet transmission', 'global health', ‘epidemiology', 'virus', 'prevention', 'coronavirus treatment', 'severe acute respiratory syndrome', 'disinfection', 'transmission' 'SARS' 'SARSCoV-2', 'coronaviruses', 'enveloped viruses', 'virus stability', 'COVID-19 stability', 'virus transmission', 'host responses to virus', '2019-nCOV'. 'SARS-CoV-2 entry points', 'respiratory virus', 'air pollution, 'handwashing', 'pollution mask', 'face masks', 'infection risk reduction', 'rural handwashing', 'face touching', 'coughing and sneezing', 'virus outbreak', 'mass gatherings', 'biocidal agents virus', 'utensil sharing risk', 'cutlery sharing risk', 'respiratory hygiene', 'toilet plume', 'phone hygiene'. 'COVID-19 policies', 'sodium hypochlorite disinfection', 'alcohol disinfection', 'carbon footprint', 'water supply scarcity', 'influenza', 'swine flu', 'social isolation', 'quarantine', 'social distancing', 'open defecation', 'WHO COVID-19', 'CDC COVID-19', 'COVID-19 advice', 'respiratory emission', 'ethics COVID-19', 'hygiene education'. Primary prevention measures as well as risk factors for infectious disease transmission were reviewed in order to generate ten core preventative measures for discussion. The avoidance of cutlery sharing, for example, was generated after determining it as a highly preventable risk for infectious disease transmission. Three independent reviewers engaged in the review and agreed on the final research used.

The literature was categorised according to the Oxford Centre for Evidence-Based Medicine (OCEBM) Levels of Evidence (Fig. 1) ${ }^{13}$, which systemises strength of evidence into levels, based on process of study design and methodology.

Fig 1. The Oxford Centre for Evidence-Based Medicine (OCEBM) Levels of Evidence ${ }^{13}$
LEVEL
THERAPY / PREVENTION, AETIOLOGY / HARM
$1 \mathrm{~A}$
Systematic Review (SR) (with homogeneity) of Randomised Controlled Trials (RCTs)
$1 B$
Individual RCT (with narrow Confidence Interval)
1C All or none 
2A

2B

2C

3A

3B

4

5

SR (with homogeneity) of cohort studies

Individual cohort study (including low quality RCT; e.g., $<80 \%$ follow-up)

"Outcomes" Research; Ecological studies

SR (with homogeneity) of case-control studies

Individual Case-Control Study

Case-series (and poor quality cohort and case-control studies)

Expert opinion without explicit critical appraisal, or based on physiology, bench research or "first principles"

\section{Results}

The search identified 105 relevant publications, all of which were reviewed and included in the results analysis. The search identified ten bottom-up, non-pharmaceutical, primary prevention measures, based on the health-EDRM framework. The review of evidence is disaggregated into the ten prevention measures.

Six personal protective practices (engage in regular handwashing, wear face mask, avoid touching the face, cover mouth and nose when coughing and sneezing, bring personal utensils for when dining out, closing toilet cover when flushing), two household practices (disinfect household surfaces, avoid sharing cutlery) and two community practices (avoid crowds and mass gatherings, avoid travel) were identified. Tables $1 a, l b$ and $1 c$ highlight the potential health risk; desired behavioural changes; potential health co-benefits; enabling and limiting factors; and strength of evidence available in published literature with regards to these measures.

Table 2 categorises all 105 reviewed publications according to the OCEBM Levels of Evidence $^{13}$. Details each utilised reference can be found in Appendix 1. Quantity of evidence varies between each of ten measures reviewed, with handwashing and face mask practices having the most published resources available. Only a few systematic and longitudinal studies could be identified. Available evidence consists of predominantly level IV and V studies, and mainly of cross-sectional studies, guidelines and expert opinion. 
Table 1a (Part 1): Personal practices as preventive measure - risk; behavioural change; health co-benefits; enabling and limiting factors; and strength of evidence

\begin{tabular}{|c|c|c|c|}
\hline & Engage in Regular Handwashing & Wear Face Mask & Avoid Touching the Face \\
\hline Risk & $\begin{array}{l}\text { - COVID-19 is transmittable through respiratory } \\
\text { fluid droplets, }{ }^{4,14} \text {. } \\
\text { - Droplets can persist on hands and other } \\
\text { surfaces }^{15} \text {. } \\
\text { - Droplets may be transferred if hands are not } \\
\text { disinfected. }\end{array}$ & $\begin{array}{l}\text { - Respiratory droplets from other individuals and hand-to- } \\
\text { face contacts can result in droplet intake through the nose } \\
\text { and mouth }{ }^{16,17,4} \text {. } \\
\text { - Viruses have the potential to survive in the respiratory } \\
\text { tract }^{18} \text {. The virus may also enter through ocular means, } \\
\text { although studies focusing specifically on COVID-19 are } \\
\text { limited }{ }^{19} \text {. } \\
\text { - COVID-19 has an incubation period of as long as } 19 \\
\text { days }{ }^{20} \text {; asymptomatic or mildly symptomatic individuals } \\
\text { may spread the virus through coughing or sneezing. } \\
\text { - In 2010, WHO stated that where there is improper mask } \\
\text { usage, risk may increase }{ }^{21} \text {. }\end{array}$ & $\begin{array}{l}\text { - Recent research has suggested that nasal carriage } \mathrm{e}^{22} \text { and ocular } \\
\text { entry }^{19} \text { are key alternative routes to oral entry into the respiratory } \\
\text { tract for COVID-19. } \\
\text { - It has been demonstrated that COVID-19 can be detected on } \\
\text { surfaces of plastic, stainless steel, copper and cardboard for up to } 72 \\
\text { hours }{ }^{15} \text { after contamination. Hand-to-face contact following contact } \\
\text { of public surfaces may pose a risk. }\end{array}$ \\
\hline $\begin{array}{l}\text { Behavioural } \\
\text { Change }\end{array}$ & $\begin{array}{l}\text { - Wash hands with soap }{ }^{23,24,25,26,27,28,20,29} \text { for a } \\
\text { minimum of } 20 \text { seconds using a step-by-step } \\
\text { guideline such as the WHO healthcare-based } \\
11 \text {-step guideline }{ }^{30} \text {. } \\
\text { - Wash hands before eating, after bathroom } \\
\text { usage, after mask removal et cetera. } \\
\text { - Practice alternative handwashing routines as } \\
\text { long as they maintain the core principle of } \\
\text { ensuring that the entire surface area of the } \\
\text { hands is scrubbed }{ }^{31} \text {. } \\
\text { - Ensure commonly missed areas are washed, } \\
\text { such as the thumbs and fingertips }{ }^{32,33,34,35} \text {. }\end{array}$ & $\begin{array}{l}\text { - Wear surgical face masks } \mathrm{s}^{36,37,38,39,28,20,29} \text { to create a } \\
\text { physical barrier preventing the spread or intake of the } \\
\text { virus-containing respiratory droplet (which are released } \\
\text { by coughing or sneezing) through facial openings }{ }^{40} \text {. } \\
\text { - Wear face masks to minimise the touching of the nose } \\
\text { and mouth as these can serve as transmission routes for } \\
\text { COVID- } 19^{16,41,17,4} \text {. } \\
\text { - Use face masks correctly to ensure the best overall } \\
\text { effectiveness, including one-time usage; limiting usage } \\
\text { to one day; and avoid touching the surface to minimise } \\
\text { risk of self-contamination }{ }^{42,43} \text {. }\end{array}$ & $\begin{array}{l}\text { - Avoid touching the face to minimise the risk of COVID- } 19 \text { contact } \\
\text { through the body's main entry points for transmittable } \\
\text { conditions } \mathrm{s}^{44,36,27,28,29} \text { : the mouth, the eyes and the nose. } \\
\text { - Exercise increased awareness of this unwanted practice to minimise } \\
\text { the risk of infection, as self-touching of the face may be } \\
\text { spontaneous }{ }^{45,46} \text {. }\end{array}$ \\
\hline Co-benefit(s) & $\begin{array}{l}\text { - Prevention of other contact-transmissible } \\
\text { diseases such as influenza }{ }^{47,48} \text {, to some extent, } \\
\text { diarrhoea }{ }^{49,50} \text { and eye infections }{ }^{51} \text {. } \\
\text { - Potential for reduced infection transmission in } \\
\text { community and household }{ }^{52} \text {. }\end{array}$ & $\begin{array}{l}\text { - Protection against other microbes transmitted by } \\
\text { respiratory droplets through the nose, mouth or eyes }{ }^{19,22} \text {. } \\
\text { - Protection from air pollutants and other air particles }{ }^{53,54} \text {, } \\
\text { which could cause other respiratory conditions }{ }^{55} \text { such as } \\
\text { asthma and lung cancer }{ }^{56,57} \text {. }\end{array}$ & $\begin{array}{l}\text { - Minimises contracting diseases with similar transmission pathways } \\
\text { such as influenza }{ }^{58,44} \text {. } \\
\text { - Reduce risk of transferring bacterial pathogens found on hands }{ }^{59} \text {. }\end{array}$ \\
\hline $\begin{array}{l}\text { Enabling } \\
\text { Factor(s) }\end{array}$ & $\begin{array}{l}\text { - Availability and affordability of running and } \\
\text { sufficient water, soap and alcohol-based rubs. }\end{array}$ & $\begin{array}{l}\text { - Access to effective face masks. } \\
\text { - Information about the correct use of face masks, }\end{array}$ & $\begin{array}{l}\text { - Effectiveness may be limited for infants, children, and others who } \\
\text { do not have sufficient conscious control of body movement. }\end{array}$ \\
\hline
\end{tabular}




\begin{tabular}{|c|c|c|c|}
\hline & & $\begin{array}{l}\text { including proper disposal. } \\
\text { - Information about when to wear facemasks. } \\
\text { - Socio-cultural acceptance and habit on wearing face } \\
\text { masks (global East vs. West) }\end{array}$ & \\
\hline $\begin{array}{l}\text { Limiting } \\
\text { Factor(s) } \\
\text { and/or } \\
\text { Alternative(s) }\end{array}$ & $\begin{array}{l}\text { - Alcohol-based formulas as alternative; } \\
\text { efficacy in killing enveloped viruses has been } \\
\text { demonstrated }^{60} \text {. } \\
\text { - Use of ash and mud as an alternative in areas } \\
\text { where there is no access to soap or alcohol- } \\
\text { based rubs, Although these carry potential } \\
\text { antimicrobial properties }{ }^{61} \text {, their efficacy in } \\
\text { counteracting viral infections is not well- } \\
\text { evidenced }{ }^{62} \text {. } \\
\text { - In areas with scarce running water, sharing } \\
\text { and reusing of water or water-container } \\
\text { elevates risk of transmission through droplets }{ }^{63} \text {. }\end{array}$ & $\begin{array}{l}\text { - For those who cannot access surgical face masks, due to } \\
\text { affordability, availability or otherwise, homemade } \\
\text { masks }{ }^{64} \text { accompanied with the same hygienic measures } \\
\text { can be considered }^{65} \text {. }\end{array}$ & $\begin{array}{l}\text { - Where face-touching is necessary or difficult to control, for } \\
\text { example in infants or children, handwashing will be a more } \\
\text { effective prevention measure. }\end{array}$ \\
\hline $\begin{array}{l}\text { Strength of } \\
\text { Evidence }\end{array}$ & $\begin{array}{l}\text { - Published evidence showed handwashing is a } \\
\text { core community prevention measure for } \\
\text { COVID-19 transmission. } \\
\text { - Handwashing communities display lower risks } \\
\text { of developing transmittable diseases when } \\
\text { compared to their non-handwashing } \\
\text { counterparts, in both rural }{ }^{61} \text { and urban } \\
\text { populations }{ }^{66} \text {. } \\
\text { - The measure is recommended by multiple } \\
\text { governing bodies, including the WHO }{ }^{36} \text { and } \\
\text { CDC }^{37} \text {. } \\
\text { - Studies from Severe Acute Respiratory } \\
\text { Syndrome (SARS), although not conclusive, } \\
\text { are suggestive of handwashing as an effective } \\
\text { measure }{ }^{67} \text {. } \\
\text { - } 20 \text {-seconds may be considered a minimum } \\
\text { duration given that time reductions, for } \\
\text { example to } 5 \text { seconds }{ }^{68} \text { have been demonstrated } \\
\text { as less effective. } \\
\text { - Soap and alcohol-based rubs are well- } \\
\text { evidenced in their capability to interact with } \\
\text { and degrade enveloped viruses }{ }^{38,60} \text {. } \\
\text { - Evidence of ash or mud-based alternatives as } \\
\text { antimicrobials is limited; no concrete evidence }\end{array}$ & $\begin{array}{l}\text { - Multiple extensive studies on the similar SARS } \\
\text { coronavirus concluded that there is evidence of effective } \\
\text { transmission risk reduction } n^{69,23,24,25} \text {. One study states } \\
\text { uncertainty over the effectiveness }{ }^{70} \text {. } \\
\text { - Success of Hong Kong and Taiwan's high compliance to } \\
\text { mask-wearing practices }{ }^{71} \text { has been potentially reflected } \\
\text { in the low rate of locally infected cases of COVID-19 } 9^{72} \text {, } \\
\text { with both communities having reported periods of no } \\
\text { new infections despite initial surges }{ }^{73} \text {. } \\
\text { - Used in conjunction with other practices such as social } \\
\text { distancing, a model simulation demonstrate community- } \\
\text { wide benefits of mask-wearing }{ }^{74} \text {. }\end{array}$ & $\begin{array}{l}\text { - Such measures have been recommended for influenza in the past }{ }^{26} \text {. } \\
\text { - There is strong evidence of viral infections entering through the } \\
\text { facial entry points and has been demonstrated for COVID-1922, } \\
\text { although evidence for impact of face-touching in disease- } \\
\text { transmission was not found. } \\
\text { - The stability of COVID-19 virus on certain surfaces has been } \\
\text { evidenced. Similarly, previous studies have demonstrated the } \\
\text { stability of other coronaviruses such as SARS, on such surfaces }\end{array}$ \\
\hline
\end{tabular}


with respect to efficacy against COVID-19 or

other viral infections.

Table 1a (Part 2): Personal practice as preventive measure - risk; behavioural change; health co-benefits; enabling and limiting factors; and strength of evidence

\begin{tabular}{|c|c|c|c|}
\hline & Cover Mouth and Nose when Coughing and Sneezing & $\begin{array}{c}\text { Bring Personal Utensils when Dining } \\
\text { Out }\end{array}$ & Close Toilet Cover when Flushing \\
\hline Risk & $\begin{array}{l}\text { - COVID-19 is transmittable through droplets }{ }^{14} \text {, and has the potential } \\
\text { to remain stable on surfaces up to } 72 \text { hours }^{15} \text {. Open coughing, } \\
\text { sneezing, and talking, may directly or indirectly transmit COVID-19 } 19^{44} \text {. } \\
\text { Research suggests that such pathogen-bearing droplets can travel up to } \\
7-8 \text { metres }{ }^{76} \text {. }\end{array}$ & $\begin{array}{l}\text { - There is a high possibility of COVID- } \\
19 \text { transmission through saliva }^{77,78} \text { in instances where public } \\
\text { droplets }^{7,78} \text { utensils are not sufficiently } \\
\text { disinfected }^{79,80} \text {. }\end{array}$ & $\begin{array}{l}\text { - There is growing evidence of COVID-19 being present in } \\
\text { stool after clearance through the respiratory tract }{ }^{81,82} \text {. } \\
\text { - Virus particles present in stool can be transmitted through } \\
\text { toilet plume generated after flushing }{ }^{33,84} \text {, especially if the } \\
\text { toilet is unclosed. }\end{array}$ \\
\hline $\begin{array}{l}\text { Behavioural } \\
\text { Change }\end{array}$ & $\begin{array}{l}\text { - Cough/sneeze into tissue paper that is disposed immediately. } \\
\text { - Replace mask after a major sneeze. } \\
\text { - Cough or sneeze into elbow or shirt if mask or tissue is unavailable }{ }^{85} \text {. } \\
\text { - These practices }{ }^{36,37,38,25,20,29} \text { minimise droplet landings on the hands, } \\
\text { which are most likely to come into contact with oneself and other } \\
\text { surfaces. Hands should be disinfected after coughing or sneezing. }\end{array}$ & $\begin{array}{l}\text { - Avoid food consumption with public } \\
\text { utensils, or utensils that have not been } \\
\text { confirmed to be disinfected. } \\
\text { - Use personal utensils }{ }^{86,29,87} \text { that have } \\
\text { been appropriately disinfected for food } \\
\text { consumption. }\end{array}$ & $\begin{array}{l}\text { - Cover toilets prior to flushing, both at home and in public. } \\
\text { - Avoid public toilets during such a pandemic, especially } \\
\text { those with toilets lacking lids }{ }^{88} \text {. }\end{array}$ \\
\hline Co-benefit(s) & - Minimising risk of other droplet-transmittable diseases ${ }^{44}$. & $\begin{array}{l}\text { - Prevention of other diseases that are } \\
\text { transmitted through saliva }{ }^{58} \text {. }\end{array}$ & $\begin{array}{l}\text { - Improved household hygiene and protection from } \\
\text { pathogens present in stool, such as bacterial or norovirus } \\
\text { infections causing gastroenteritis }{ }^{84} \text {. }\end{array}$ \\
\hline $\begin{array}{l}\text { Enabling } \\
\text { Factor(s) }\end{array}$ & $\begin{array}{l}\text { - Access to masks and tissue. } \\
\text { - Adequate mobility and reaction to raise elbow or tissue to the face. }\end{array}$ & $\begin{array}{l}\text { - Access to personal reusable or single- } \\
\text { use utensils. }\end{array}$ & - Access to a toilet with a functional lid. \\
\hline $\begin{array}{l}\text { Limiting } \\
\text { Factor(s) } \\
\text { and/or } \\
\text { Alternative(s) }\end{array}$ & $\begin{array}{l}\text { - People with limited mobility, such as the elderly }{ }^{89,90} \text {, may not be able } \\
\text { to react in time. The alternative is to maximise mask wearing as a } \\
\text { permanent physical barrier. }\end{array}$ & $\begin{array}{l}\text { - May not be applicable to contexts } \\
\text { where eating with hands is the } \\
\text { tradition. Handwashing should be the } \\
\text { primary preventive measure in these } \\
\text { contexts. } \\
\text { - Where personal utensils are not } \\
\text { available, single-use utensils can be } \\
\text { considered, although there are } \\
\text { environmental implications of } \\
\text { disposable utensils }{ }^{91,92} \text {. }\end{array}$ & $\begin{array}{l}\text { - Another study has suggested that due to space between the } \\
\text { lid and the toilet bowl, shutting the lid may not impede } \\
\text { emissions entirely }{ }^{93} \text {. } \\
\text { - For households lacking lidded toilets, other protective } \\
\text { measures include regular cleaning; wearing a face amsk } \\
\text { during toilet usage; and avoiding sharing toilets. }\end{array}$ \\
\hline
\end{tabular}




\begin{tabular}{|c|c|c|c|}
\hline $\begin{array}{l}\text { Strength of } \\
\text { Evidence }\end{array}$ & $\begin{array}{l}\text { - There is strong evidence supporting the transmission of COVID-19 } \\
\text { through respiratory droplets, which can be expelled in sneezing and } \\
\text { coughing }{ }^{94,95,27} \text {. } \\
\text { - Some evidence indicates that wearing a mask redirects coughed } \\
\text { particles to a less harmful direction }{ }^{39} \text { - similar outcome may be } \\
\text { inferred for tissue or elbow blockage although it may not be as } \\
\text { effective. } \\
\text { - There is lacking evidence on how each of the behavioural changes } \\
\text { contribute to risk reduction for COVID-19 specifically. }\end{array}$ & $\begin{array}{l}\text { - There is no specific evidence of } \\
\text { COVID-19 transmitting through public } \\
\text { cutlery. } \\
\text { - Limited evidence suggesting } \\
\text { restaurants or caterers fail to properly } \\
\text { disinfect their reusable cutlery. }\end{array}$ & $\begin{array}{l}\text { - Although this has not been directly confirmed, there is } \\
\text { growing evidence that COVID- } 19 \text { may be present in stool. } \\
\text { - There is evidence that toilet plumes ascend when toilets } \\
\text { remain open. } \\
\text { - This measure has been suggested by authorities in places } \\
\text { such as Hong Kong }{ }^{28} \text {. }\end{array}$ \\
\hline
\end{tabular}

Table 1b: Household practices as preventive measure - risk; behavioural change; health co-benefits; enabling and limiting factors; and strength of evidence

\begin{tabular}{|c|c|c|}
\hline & Disinfect Household Surfaces & Avoid Sharing Utensils \\
\hline Risk & $\begin{array}{l}\text { - COVID-19 has varying stability on different household surfaces, including metal, wood, glass, plastic, } \\
\text { paper and stee } 1^{96} \text {. } \\
\text { - Personal belongings such as mobile phones and laptops have been shown to carry a high load of } \\
\text { bacteria }^{97,98} \text { due to inadequate cleansing and lots of hand-contact. The same may apply for virus particles. }\end{array}$ & $\begin{array}{l}\text { - Studies have previously demonstrated cutlery sharing practices as a } \\
\text { risk for oral transmission }{ }^{99} \text {. } \\
\text { - Due to the high possibility of COVID-19 transmission through saliva } \\
\text { droplets }{ }^{77,78} \text {, it may pose similar risk. } \\
\text { - There is additional unknown risk due to potential for asymptomatic } \\
\text { transmission }{ }^{20} \text {. }\end{array}$ \\
\hline $\begin{array}{l}\text { Behavioural } \\
\text { Change }\end{array}$ & $\begin{array}{l}\text { - Disinfect households regularly }{ }^{37,24,25,27,28,29} \text {, especially frequently touched objects and surfaces }{ }^{43} \text {, with } \\
\text { biocidal agents such as } 62-71 \% \text { ethanol, } 0.1 \% \text { sodium hypochlorite or } 0.5 \% \text { hydrogen peroxide }{ }^{75} \text {. } \\
\text { - Use a dilution of 1:50 bleach for general household disinfecting of flooring and doors }{ }^{75} \text {. } \\
\text { - Disinfect smaller objects, such as keys, or surfaces that come in contact with the face and mouth, such as } \\
\text { mobile phones, with } 62-71 \% \text { ethanol or alcohol wipes instead }{ }^{75} \text {, due to potential hazards from bleach }{ }^{100} \text {. }\end{array}$ & $\begin{array}{l}\text { - Avoid sharing of utensils or serving food from a communal dish with } \\
\text { used utensils. } \\
\text { - Use designated serving-utensils to prevent saliva-based droplet } \\
\text { transmission. } \\
\text { - Maintain hygiene practices, such as adequate cleaning of all utensils. }\end{array}$ \\
\hline Co-benefit(s) & $\begin{array}{l}\text { - Improved general household hygiene, such as mould reduction }{ }^{101,102} \text {. } \\
\text { - Opportunity for mild physical activity to compensate for lack of outdoor exercise during COVID-19 } \\
\text { social isolation. }\end{array}$ & $\begin{array}{l}\text { - Reduced risk of other saliva-transmitted bacteria while utensil- } \\
\text { sharing }^{86} \text {. } \\
\text { - Reduced risk of dental caries transmission }{ }^{103} \text {. }\end{array}$ \\
\hline $\begin{array}{l}\text { Enabling } \\
\text { Factor(s) }\end{array}$ & $\begin{array}{l}\text { - Access to proper disinfectants. } \\
\text { - Knowledge on safe use and storage of disinfectants. }\end{array}$ & $\begin{array}{l}\text { - Availability of serving utensils. } \\
\text { - Cultural appropriateness, such as when seating in settings where such } \\
\text { sharing is expected. }\end{array}$ \\
\hline $\begin{array}{l}\text { Limiting } \\
\text { Factor(s) } \\
\text { and/or } \\
\text { Alternative(s) }\end{array}$ & $\begin{array}{l}\text { - Where resources are limited, households should use the best disinfectant possible, reduce the frequency of } \\
\text { disinfection, or target frequently touched surfaces such as door handles. }\end{array}$ & $\begin{array}{l}\text { - Where appropriate, hand-consumption after adequate handwashing } \\
\text { may be considered to avoid utensil-sharing. Proper handwashing } \\
\text { practices must be observed. }\end{array}$ \\
\hline
\end{tabular}




\begin{tabular}{|c|c|c|}
\hline $\begin{array}{l}\text { Strength of } \\
\text { Evidence }\end{array}$ & $\begin{array}{l}\text { - Studies exist on the effectiveness of various household disinfectants against other viruses, including } \\
\text { coronaviruses }{ }^{75} \text {. } \\
\text { - Evidence on the effectiveness against COVID-19 specifically is lacking. }\end{array}$ & $\begin{array}{l}\text { - Given its transmission through droplets }{ }^{14} \text {, and persistence in saliva }{ }^{77} \text {, } \\
\text { this prevention measure should be considered good practice. } \\
\text { - This measure was recommended by the CDC during the } 2003 \text { SARS } \\
\text { outbreak }^{29} \text {. } \\
\text { - There is no study on the impact of utensil-sharing on COVID-19 } \\
\text { specifically. } \\
\text { - Studies have noted potential spread of H. Pylori via shared } \\
\text { chopsticks }^{87} \text {. }\end{array}$ \\
\hline
\end{tabular}

Table 1c: Community practice as preventive measure - risk; behavioural change; health co-benefits; enabling and limiting factors; and strength of evidence

\begin{tabular}{|c|c|c|}
\hline & Avoid Crowds and Mass Gatherings & Avoid Travel \\
\hline Risk & $\begin{array}{l}\text { - Crowded areas with unknown people are considered high-risk due to risk of droplet transmission } \\
\text { and infection through contaminated surfaces. } \\
\text { - Talking can potentially result in respiratory infectious disease transmission }{ }^{104} \text {. } \\
\text { - Possibility of transmission by asymptomatic carriers within a crowd increases risk }{ }^{105} \text {. }\end{array}$ & $\begin{array}{l}\text { - Travelling to areas with confirmed cases will increase an individual's risk } \\
\text { of potential exposure to COVID- } 19 \text {. } \\
\text { - The stability of the virus on surfaces }{ }^{15} \text {, the potential prevalence of } \\
\text { asymptomatic carriers }{ }^{105} \text {, the difficulty and lack of distancing }{ }^{106} \text {, shared } \\
\text { toilets and risk of toilet plume }{ }^{82} \text {, and uncertain travel history of others } \\
\text { make environments such as trains and aeroplanes challenging in terms of } \\
\text { protection and high risk in terms of COVID-19 transmission. }\end{array}$ \\
\hline $\begin{array}{l}\text { Behavioural } \\
\text { Change }\end{array}$ & $\begin{array}{l}\text { - Observe social distancing measures } 4,14,37,74,27,28,20,29,107 \\
\text { - A separation of } 1 \text { metre is the minimum as recommended by the } \mathrm{WHO}^{36} \text {. Although most droplets } \\
\text { may not travel across this distance, novel studies exploring the influence of aerodynamics }{ }^{108} \text { as well } \\
\text { as the potential for sneezes to travel up to } 8 \text { meters }^{76} \text { have led to the recommendation that possible } \\
\text { distancing should be maintained wherever possible. } \\
\text { - Avoid congregating and take precaution when in public areas such as parks, cinemas, restaurants. } \\
\text { These areas should make face mask wearing mandatory, carry out temperature checks, limit the } \\
\text { number of people in attendance, and practice distancing of people. }\end{array}$ & $\begin{array}{l}\text { - Avoid travelling to areas with confirmed cases, which are of significant } \\
\text { risk } k^{28,20,29} \text {. } \\
\text { - Take all necessary personal protective measures such as wearing of face } \\
\text { masks, eye googles, disinfecting immediate area with alcohol-based } \\
\text { solution and avoiding food sharing. } \\
\text { - Implement (for authorities) appropriate protective measures such as } \\
\text { mandatory temperature checks prior to travel and/or upon arrival, reporting } \\
\text { the travel and medical history of each traveller, and distancing } \\
\text { requirements on transport. }\end{array}$ \\
\hline Co-benefit(s) & $\begin{array}{l}\text { - Reduced outdoor pollution due to minimised outdoor human activity }{ }^{109,110} \text {. } \\
\text { - Lower exposure to outdoor air pollution which causes respiratory illnesses such as lung cancer and } \\
\text { contributes to mortality }{ }^{11,55} \text {. }\end{array}$ & $\begin{array}{l}\text { - Reduction of cross-border transmission }{ }^{107} \text {. } \\
\text { - Improved general hygiene on transport such as trains or aeroplanes } \\
\text { - Environmental benefit from reduced air-travel carbon footprint }{ }^{12} \text {. }\end{array}$ \\
\hline $\begin{array}{l}\text { Enabling } \\
\text { Factor(s) }\end{array}$ & - Ability to avoid crowded areas as permissible by population density, occupation, religion or culture. & - Ability to make decisions on when or how to travel. \\
\hline
\end{tabular}




\begin{tabular}{|l|l|l|}
\hline $\begin{array}{l}\text { Limiting } \\
\text { Factor(s) } \\
\text { and/or } \\
\text { Alternative(s) }\end{array}$ & $\begin{array}{l}\text { - Crowded areas may not be avoidable due to occupation, religious belief or otherwise. Where } \\
\text { gathering is necessary, individuals should take personal responsibility to wear masks, keep hands } \\
\text { clean, and maintain maximum distance from others. }\end{array}$ & $\begin{array}{l}\bullet \text { Access to facemasks, goggles or alcohol-based solution for personal } \\
\text { protection during travel. } \\
\text { The necessity of travel, for personal or professional reasons, such as pilots } \\
\text { and the cabin crew. }\end{array}$ \\
\hline $\begin{array}{l}\text { Strength of } \\
\text { Evidence }\end{array}$ & $\begin{array}{l}\text { - Studies on influenza and COVID-19 } \\
\text { limiting transmission }{ }^{114} \text {, though studies are limited and not yet conclusive. } \\
\text { There are also studies on the elevated transmission of other viruses as a result of mass } \\
\text { gatherings }{ }^{115,116,117} \text {. }\end{array}$ & $\begin{array}{l}\text { The proximity and contact with individuals heighten the evidenced risk of } \\
\text { taking in potential respiratory droplets containing COVID-19 from others. } \\
\text { specifically. }\end{array}$ \\
\hline
\end{tabular}

Table 2: Number of referenced articles per measure by OCEBM categorisation level

\begin{tabular}{|c|c|c|c|c|c|c|c|c|c|c|c|c|c|}
\hline \multirow[t]{2}{*}{ Category } & \multirow[t]{2}{*}{ Primary preventive measure } & \multicolumn{12}{|c|}{ Number of referenced articles per OCEBM categorisation level } \\
\hline & & 1a & $\mathbf{1 b}$ & 1c & $2 \mathbf{a}$ & $2 \mathbf{b}$ & $2 c$ & 3a & $3 \mathbf{b}$ & 4 & 5 & Others & Total \\
\hline \multirow{6}{*}{$\begin{array}{l}\text { Personal } \\
\text { Practices }\end{array}$} & Engage in Regular Handwashing & 4 & 5 & 0 & 0 & 1 & 0 & 2 & 2 & 3 & 17 & 0 & 34 \\
\hline & Wear Face Mask & 0 & 3 & 0 & 0 & 1 & 0 & 0 & 2 & 7 & 18 & 1 & 32 \\
\hline & Avoid Touching the Face & 0 & 0 & 0 & 0 & 2 & 0 & 0 & 0 & 1 & 10 & 0 & 13 \\
\hline & $\begin{array}{l}\text { Cover Mouth and Nose when } \\
\text { Coughing and Sneezing }\end{array}$ & 0 & 0 & 0 & 0 & 0 & 0 & 0 & 0 & 2 & 15 & 0 & 17 \\
\hline & $\begin{array}{l}\text { Bring Personal Utensils for When } \\
\text { Dining Out }\end{array}$ & 0 & 0 & 0 & 0 & 0 & 0 & 0 & 0 & 2 & 8 & 0 & 10 \\
\hline & $\begin{array}{l}\text { Close Toilet Cover } \text { When } \\
\text { Flushing }\end{array}$ & 0 & 0 & 0 & 0 & 0 & 0 & 0 & 0 & 2 & 6 & & 8 \\
\hline \multirow{2}{*}{$\begin{array}{l}\text { Household } \\
\text { Practices }\end{array}$} & Disinfect Household Surfaces & 0 & 0 & 0 & 0 & 0 & 0 & 0 & 1 & 1 & 11 & 0 & 13 \\
\hline & Avoid Sharing Utensils & 0 & 0 & 0 & 0 & 1 & 0 & 0 & 0 & 4 & 4 & 0 & 9 \\
\hline \multirow[t]{2}{*}{$\begin{array}{l}\text { Community } \\
\text { Practices }\end{array}$} & $\begin{array}{l}\text { Avoid Crowds and Mass } \\
\text { Gatherings }\end{array}$ & 0 & 0 & 0 & 0 & 0 & 0 & 0 & 0 & 2 & 21 & 0 & 23 \\
\hline & Avoid Travel & 0 & 0 & 0 & 0 & & 0 & 0 & 0 & 3 & 6 & 0 & 9 \\
\hline \multicolumn{2}{|l|}{ Total } & 4 & 8 & 0 & 0 & 5 & 0 & 2 & 5 & 27 & 116 & 1 & $168 *$ \\
\hline
\end{tabular}

* Some of the 105 publications are referenced against more than one of the ten primary preventive measures. 
medRxiv preprint doi: https://doi.org/10.1101/2020.05.29.20116475; this version posted May 29, 2020. The copyright holder for this preprint

(which was not certified by peer review) is the author/funder, who has granted medRxiv a license to display the preprint in perpetuity.

It is made available under a CC-BY-NC-ND 4.0 International license .

\section{Discussion}

Evidence relating to ten health-EDRM behavioural measures for primary prevention against droplet-borne biological hazards were identified and reviewed. At the time of writing, there is an outstanding question as to whether COVID-19 is transmitted through droplet or aerosol in the community. The information referenced here is based on best available evidence, and will need to be updated as new studies and guidelines are published, and the understanding of the scientific community is enhanced. Although direct evidence on the efficacy of prevention measures against COVID-19 specifically is lacking due to the novelty of the disease, five behavioural measures were identified: regular handwashing; wearing of face masks; avoidance of face touching; covering during sneezing or coughing; and household disinfecting were identified. Five other potential behavioural measures were also identified through logical deductions from potential behavioural risks associated with transmission of diseases similar to COVID-19 ${ }^{75}$. Utensilrelated practices, in particular, were heavily limited in evidence to support their efficacy against viral infections.

The efficacy and success of the ten bottom-up primary prevention measures reviewed here are subject to specific enabling and limiting determinants, ranging from demographic (e.g. age, gender, education), socio-cultural, economic (e.g. financial accessibility to commodities), and knowledge (e.g. understanding of risk, equipment use). The viability and efficacy of each measure may be limited by determinants and constraints in different contexts. Resource-deprived areas may face constraints and reduced effectiveness of implementation, especially for measures that require preventive commodities such as face masks and household disinfectants. As such, special attention should be given to rural settings, informal settlements, and resource-deficit contexts where access to information and resources such as clean water supply are often limited $^{119,120}$, and sanitation facilities are lacking ${ }^{121}$. For hygiene measures, different alternatives should be promoted and their relative scientific merits should be evaluated, such as the use of ash as an alternative to soap for handwashing ${ }^{62}$, or the efficacy of handwashing with alcohol sanitiser, which has been demonstrated in previously-published studies for $\mathrm{H} 1 \mathrm{~N} 1^{122}$ and noroviruses ${ }^{123}$ but not yet for COVID-19. Meanwhile, for measures that have no direct alternatives available, it is important for authorities and policymakers to understand the capacity limitations of certain target groups, and provide additional support or put in place other preventive measures. In cases where material resources are scarce, the measures of awareness on sneezing and coughing etiquette as well as avoiding hand-to-face contact are the most convenient to adopt as they require little to no commodities. However, it should be well-noted that these measures are likely the most challenging in compliance and enforceability, as they rely on the modification of frequent and natural human behaviours whose modifications would require awareness and practice ${ }^{45,46}$. Furthermore, these can be challenging to implement in target groups with less capacity for health literacy and translation of education into practice, such as infants and elderly suffering from dementia. Cultural patterns can be associated with behavioural intentions, in the case of avoiding 
medRxiv preprint doi: https://doi.org/10.1101/2020.05.29.20116475; this version posted May 29, 2020. The copyright holder for this preprint (which was not certified by peer review) is the author/funder, who has granted medRxiv a license to display the preprint in perpetuity. It is made available under a CC-BY-NC-ND 4.0 International license .

utensil-sharing during meals, enforcing change may be conflicted with cultural and traditional norms in Asia and certain European communities ${ }^{124}$.

Of the enabling factors documented for each proposed measure, shared enablers can be identified: accessibility and affordability of resources; related knowledge, awareness and understanding of risk; and associated top-down policy facilitation. Majority of personal and household practices heavily rely on access to resources, such as adequate water and soap supply for regular handwashing, quality face masks and household-disinfectants. Various theories of the 'Knowledge, Attitudes, Practices' model have assumed that individual knowledge enhancement will lead to positive behavioural changes ${ }^{118}$. Health measures targeting mask-wearing might aim to enhance (1) the individual's risk perception, knowledge and awareness on protection effectiveness of masks, and how to properly wear a mask so that the prevention is most effective; (2) an individual or community's attitude towards the practice of mask-wearing and encouraging compliance in the West, as studies demonstrate a relatively greater social stigmatisation towards mask-wearing amongst Westerners than East Asians ${ }^{125}$, and (3) normalising the practice of habitual mask-wearing. Such a conceptual framework should be utilized in the implementation of the health initiatives. In terms of overarching knowledge, health education on symptomidentification is also important, as seen on government platforms such as the $\mathrm{CDC}^{37}$. Enhancing health-seeking behaviour of potential carriers is critical to promoting a rapid response for quarantine or hospitalisation.

At the individual level, behavioural changes have different sustainability potentials and limitations. Measures can also result in unintended consequences, such as the improper disposal of face masks ${ }^{126}$ and the incorrect use of household disinfectants ${ }^{127}$ should be carefully monitored to maximise impact while minimising further health and safety risks. Top-down policy facilitation and strengthening of infrastructure will be essential for effective implementation. Top-down efforts in resource provision, such as the distribution of quality masks to all citizens by the government or similar authority ${ }^{128}$, enhance personal and household capacities to mitigate infection risks. On compliance, the effectiveness of community practices such as crowd and travel avoidance are highly dependent on the needs and circumstances of an individual and a community. More assertive top-down policies such as travel bans and social distancing rules may drive bottom-up initiatives within communities under legal deterrence ${ }^{129}$. However, in order to ensure population-level compliance to recommendations that have wideranging socioeconomic impact and involve more than a day-to-day behavioural change, careful risk and information communication is required, which takes in to consideration practical, legal and ethical aspects.

The strength of evidence available for each practice is dependent on multiple factors. In the case of a novel or emerging disease such as COVID-19, available evidence can be related specifically to the disease and pandemic, but some findings are deduced from studies on other similar viral infections and transmittable conditions, such as SARS or Influenza. Many interventions 
medRxiv preprint doi: https://doi.org/10.1101/2020.05.29.20116475; this version posted May 29, 2020. The copyright holder for this preprint (which was not certified by peer review) is the author/funder, who has granted medRxiv a license to display the preprint in perpetuity. It is made available under a CC-BY-NC-ND 4.0 International license .

proposed by health authorities are not based on rigorous population-based longitudinal studies. While handwashing is well-regarded as a core measure by global and national public health agencies such as the $\mathrm{WHO}^{36}$ and $\mathrm{CDC}^{37}$ the chemical properties of eliminating enveloped viruses is understood ${ }^{60,38}$, specific studies on the practice's efficacy and impact on COVID-19 transmission are lacking. Due to the uncertainties of disease pathology and epidemiology, effectiveness of behavioural measures against COVID-19 are far from conclusive. Other uncertainties are also reported on virus surface stability ${ }^{15}$ and if the efficacy of disinfectants against surface-stable viruses might vary with COVID-19 ${ }^{75}$. Similar deductive evidence approaches from studies on other viruses have been utilised to judge the efficacy of face masks or the shutting of toilet lids ${ }^{84,83}$. Although published evidence suggested individual measures such as covering coughs and sneezes to be helpful against droplet transmissions ${ }^{14}$, further research is needed to understand the true efficacy of coverings such as masks, tissues or elbows as an adequate preventive measure against COVID-19. Given the rapid knowledge advancement and research updates related to COVID-19, further study updates will be warranted to identify the most appropriate behavioural measures to support bottom up biological hazard responses. Cost-effectiveness of the measures, their impact sustainability, co-benefits and risk implications on other sectors should also be examined and evaluated. Standardised studies across different contexts should be enhanced, for example conducting tests on the efficacy of different disinfectants or soaps under a standardised protocol. Such studies would increase evidence on individual and comparative efficacy.

The limitations in this review include language (English language only); database inclusion (grey literature not included); online accessibility of the article; and missed keywords. Publications documenting the experiences of traditional, non-English-speaking, rural communities during the COVID-19 pandemic might not be included in this review. Further research should review the measures' efficacy in different contexts and make comparisons with their alternative measures. Specifically, alternative preventive measures that can be practiced in resource-poor, developing communities, whose health systems and economies generally suffer the greatest impact during pandemics are urgently needed. Increased understanding of how to effectively mitigate against biological hazards such as COVID-19 in various contexts will help communities prepare for future outbreaks and build disaster resilience in line with the recommendations from the healthEDRM framework.

Despite the constraints, this review has nevertheless identified common, relevant behavioural measures supported by best available evidence for the design and implementation of health policies that prevent droplet-borne biological hazards. Many of the measures recommended by authorities during the pandemic are based on best practice available rather than best available evidence. The possibility of conducting large cohort or randomised controlled studies is often complicated, and rather infeasible during a pandemic, as noted for face masks ${ }^{130,131}$. Further studies are needed to understand the efficacy of frequently proposed measures for transmission 
medRxiv preprint doi: https://doi.org/10.1101/2020.05.29.20116475; this version posted May 29, 2020. The copyright holder for this preprint (which was not certified by peer review) is the author/funder, who has granted medRxiv a license to display the preprint in perpetuity. It is made available under a CC-BY-NC-ND 4.0 International license .

risk reduction. Nonetheless, each of the measures identified has scientific basis in mitigating the risk of droplet transmission ${ }^{14}$, either through personal measures such as handwashing, or community-based measures which aim to reduce person-to-person contact. It is important to explore the efficacy of alternatives, notably for transmission prevention and risk communication in low-resources or developing contexts where the capacity of the health system to mitigate and manage emergency events outbreaks are weak. For example, while face masks are understudied, the scientific study of cloth masks as an alternative is severely limited ${ }^{65}$, although recommended by the $\mathrm{CDC}^{132}$. Such alternative studies should expand to consider different cultures and contexts where different varieties of disinfectants, face masks and utensils may be used. There is also potential for comparative effectiveness studies to explore measures that provide the greatest transmission risk reduction at the lowest transaction cost to the individual and community and should thus be prioritised in low-resource contexts ${ }^{133}$.

\section{Conclusion}

During the outbreak of a novel transmissible disease such as COVID-19, primary prevention is the strongest and most effective line of defence to reduce health risks when there is an absence of effective treatment or vaccine. COVID-19 is and will be subjected to ongoing research and scrutiny by global scientists, health professionals and policy makers. While research gaps remain on the efficacy of various health-EDRM prevention measures in risk reduction and transmission control of COVID-19, suboptimal scientific evidence does not negate the potential benefits arising from good hygiene practices, especially where the likelihood for negative outcome is minimal. Despite the lack of rigorous scientific evidence, the best available practice-based health education content, effective means of information dissemination, equitable access to resources, and monitoring of unintended consequences of the promoted measures, such as environmental pollution due to poor waste management, will be essential. A top-down approach should be multi-sectorial, bringing in policy makers with clinical, public health, environmental, and community management expertise to develop a coordinated and comprehensive approach in a globalised world.

\section{Conflict of Interest and Financial Declaration}

The authors declare no conflicts of interest. The study is fully funded by the CCOUC-University of Oxford research fund (2019-2023). 
Appendix 1: Relevant Measure(s), Study Design, Relevant Key Finding(s) and/or Conclusion of Each Utilised Reference

\begin{tabular}{|c|c|c|c|c|c|c|}
\hline $\begin{array}{l}\text { Ref. } \\
\text { No. }\end{array}$ & Title & Journal or Publication & $\begin{array}{l}\text { Date of } \\
\text { Publication }\end{array}$ & $\begin{array}{l}\text { Relevant } \\
\text { Measure(s) } \\
(\text { See Key } 1)\end{array}$ & $\begin{array}{l}\text { OCEBM Level of Evidence based on } \\
\text { Study Design (See Key 2) }\end{array}$ & Relevant Key Finding(s) and/or Conclusion \\
\hline 4 & $\begin{array}{l}\text { Modes of Transmission of Virus } \\
\text { Causing COVID-19: Implications } \\
\text { for IPC } \\
\text { Recommendations }\end{array}$ & WHO Scientific Brief & March 2020 & $\mathrm{~A}, \mathrm{~B}, \mathrm{I}$ & $\begin{array}{l}\text { Level 5: Expert opinion on precaution } \\
\text { recommendations, using research on } \\
\text { the characteristics of COVID-19 }\end{array}$ & $\begin{array}{l}\text { - With knowledge of droplet transmission (and } \\
\text { particle size), droplet and contact precautions are } \\
\text { recommended for COVID-19. } \\
\text { - Importance of PPE and other practices such as } \\
\text { frequent hand hygiene is indicated. }\end{array}$ \\
\hline 14 & $\begin{array}{l}\text { COVID-19: A Call for Physical } \\
\text { Scientists and Engineers }\end{array}$ & $\begin{array}{l}\text { American Chemical } \\
\text { Society NANO }\end{array}$ & April 2020 & $\mathrm{~A}, \mathrm{D}, \mathrm{H}, \mathrm{I}$ & $\begin{array}{l}\text { Level 5: Expert opinion based on } \\
\text { clinicians' experiences and } \\
\text { knowledge; presentation of questions, } \\
\text { hypotheses and research needs } \\
\text { regarding COVID-19 }\end{array}$ & $\begin{array}{l}\text { - Elucidates basic biology of viruses and their } \\
\text { transmission and infection pathway. } \\
\text { - Importance of handwashing and hygiene is } \\
\text { demonstrated via explanation of the need to } \\
\text { deactivate released virions before they reach a host. } \\
\text { - Identifies the major complications and } \\
\text { understandings associated with current measures } \\
\text { such as PPE and surface sanitization and make } \\
\text { recommendations accordingly. }\end{array}$ \\
\hline 15 & $\begin{array}{l}\text { Aerosol and Surface Stability of } \\
\text { SARS-CoV-2 as Compared with } \\
\text { SARS-CoV-1 }\end{array}$ & $\begin{array}{l}\text { The New England } \\
\text { Journal of Medicine }\end{array}$ & April 2020 & $\mathrm{~A}, \mathrm{C}, \mathrm{D}, \mathrm{J}$ & $\begin{array}{l}\text { Level 5: An in vitro study of the } \\
\text { surface stability of the SARS-Cov-2 } \\
\text { strain compared to SARS-CoV-1 }\end{array}$ & $\begin{array}{l}\text { - SARS-CoV-2 has similar surface stability compared } \\
\text { to SARS-CoV-1 under experimental circumstances. } \\
\text { - Demonstrates stability on surfaces such as plastic } \\
\text { and stainless steel with potential for aerosol and } \\
\text { fomite transmission. }\end{array}$ \\
\hline 16 & \begin{tabular}{lrr} 
Community & \multicolumn{2}{c}{ Transmission of } \\
Severe Acute Respiratory \\
Syndrome Coronavirus 2, \\
Shenzhen, China, 2020
\end{tabular} & $\begin{array}{l}\text { Emerging Infectious } \\
\text { Diseases }\end{array}$ & $\begin{array}{l}\text { June } 2020 \\
\text { (Early } \\
\text { Release) }\end{array}$ & B & $\begin{array}{l}\text { Level 4: A case series on confirmed } \\
\text { COVID-19 studied in order to } \\
\text { understand the pattern of community } \\
\text { transmission }\end{array}$ & $\begin{array}{l}\text { - COVID-19 became endemic to Shenzhen. } \\
\text { Community, intrafamily and nosocomial } \\
\text { transmission-routes were found. } \\
\text { - Maintenance strategies are derived, such as } \\
\text { minimising public activity, using personal protection } \\
\text { measures and the importance of early screening, } \\
\text { diagnosis and isolation. }\end{array}$ \\
\hline 17 & $\begin{array}{l}\text { A Familial Cluster of Pneumonia } \\
\text { Associated with the } 2019 \text { Novel } \\
\text { Coronavirus Indicating Person-to- } \\
\text { Person Transmission: A Study of a } \\
\text { Family Cluster }\end{array}$ & The Lancet & $\begin{array}{l}\text { February } \\
2020\end{array}$ & B & $\begin{array}{l}\text { Level 4: A case series exploring } \\
\text { epidemiological, clinical, laboratory, } \\
\text { radiology and microbiological } \\
\text { findings of a family cluster of } \\
\text { (initially) unexplained pneumonia }\end{array}$ & $\begin{array}{l}\text { - Indicating person-to-person transmission via } \\
\text { nosocomial and intrafamily means. } \\
\text { - Noted that many findings were similar to those of } \\
\text { SARS patients in } 2003 \text {. } \\
\text { - One patient was initially asymptomatic - suggestion } \\
\text { for early tracing, quarantine and control measures. }\end{array}$ \\
\hline
\end{tabular}




\begin{tabular}{|c|c|c|c|c|c|c|}
\hline 18 & $\begin{array}{l}\text { Tropism and Innate Host } \\
\text { Responses of Influenza A/H5N6 } \\
\text { Virus: An Analysis of Ex Vivo } \\
\text { and In Vitro Cultures of the } \\
\text { Human Respiratory Tract }\end{array}$ & $\begin{array}{l}\text { European Respiratory } \\
\text { Journal }\end{array}$ & March 2017 & B & $\begin{array}{l}\text { Level 5: An in vitro study on tropism, } \\
\text { replication competence and cytokine } \\
\text { induction of virus isolates in cultures } \\
\text { (Ex Vivo and In Vitro) derived from } \\
\text { human respiratory tract }\end{array}$ & $\begin{array}{l}\text { - Human H5N6 virus adapted to human airways, } \\
\text { indicating a of risk pattern for the virus upon entry } \\
\text { into respiratory tract. }\end{array}$ \\
\hline 19 & $\begin{array}{l}\text { 2019-nCoV Transmission } \\
\text { Through the Ocular Surface Must } \\
\text { Not Be Ignored }\end{array}$ & The Lancet & $\begin{array}{l}\text { February } \\
2020\end{array}$ & B & $\begin{array}{l}\text { Level 5: An ophthalmologist's expert } \\
\text { perspective on additional risk through } \\
\text { mucous membrane of eyes }\end{array}$ & $\begin{array}{l}\text { - Suggestion for consideration of studies into } \\
\text { conjunctival scrapings to look for signs of ocular } \\
\text { transmission. } \\
\text { - Ophthalmologists must wear protective eyewear } \\
\text { when examining suspect cases. }\end{array}$ \\
\hline 20 & $\begin{array}{l}\text { Presumed Asymptomatic Carrier } \\
\text { Transmission of COVID-19 }\end{array}$ & $\begin{array}{l}\text { Journal of the } \\
\text { American Medical } \\
\text { Association }\end{array}$ & $\begin{array}{l}\text { February } \\
2020\end{array}$ & $\begin{array}{l}\text { A, B, D, I, J, } \\
\mathrm{H}\end{array}$ & $\begin{array}{l}\text { Level 4: A case series on a familial } \\
\text { cluster of } 5 \text { patients with COVID-19 }\end{array}$ & $\begin{array}{l}\text { - There is a potential mechanism of COVID-19 } \\
\text { transmission via an asymptomatic carrier. } \\
\text { - Further study on the relevant mechanism is } \\
\text { suggested. }\end{array}$ \\
\hline 21 & $\begin{array}{l}\text { Emergencies } \quad \text { Preparedness, } \\
\text { Response: What Can I Do? }\end{array}$ & WHO & $\begin{array}{l}\text { January } \\
2010\end{array}$ & B & $\begin{array}{l}\text { Level 5: A compilation of } \\
\text { information on Pandemic Response } \\
\text { (2009 H1N1) protective measures }\end{array}$ & $\begin{array}{l}\text { - Regarding masks specifically, it suggests that masks } \\
\text { are only needed if you are sick. } \\
\text { - Remarks on the importance of proper mask wearing } \\
\text { practice if the measure is adopted. }\end{array}$ \\
\hline 22 & $\begin{array}{l}\text { SARS-CoV-2 Entry Factors are } \\
\text { Highly Expressed in Nasal } \\
\text { Epithelial Cells Together with } \\
\text { Innate Immune Genes }\end{array}$ & Nature Medicine & April 2020 & $\mathrm{~B}, \mathrm{C}$ & $\begin{array}{l}\text { Level 5: A study on SARS-CoV-2 } \\
\text { tropism study via study of expression } \\
\text { of viral entry-associated genes }\end{array}$ & $\begin{array}{l}\text { - Genes found to be co-expressed in nasal epithelial } \\
\text { cells, indicating a role in the initial phase of viral } \\
\text { infection, spread and clearance. }\end{array}$ \\
\hline 23 & $\begin{array}{l}\text { Use of Disposable Face Masks for } \\
\text { Public Health Protection against } \\
\text { SARS }\end{array}$ & $\begin{array}{l}\text { Journal of } \\
\text { Epidemiology and } \\
\text { Community Health }\end{array}$ & April 2004 & $\mathrm{~A}, \mathrm{~B}$ & $\begin{array}{l}\text { Level 5: Expert opinion on the use of } \\
\text { face masks and practice of personal } \\
\text { hygiene as important measures to } \\
\text { protect the general public from SARS }\end{array}$ & $\begin{array}{l}\text { - States that protection against SARS for healthcare } \\
\text { workers is different from the general public, as the } \\
\text { latter is not subject to continuous exposure to droplet } \\
\text { transmission from an infected patient. } \\
\text { - Expresses reduced risk of aerosol droplet } \\
\text { transmission with masks. } \\
\text { - Notes importance of proper usage and frequent } \\
\text { changing of masks. } \\
\text { - Also extends to mention importance of other } \\
\text { personal hygiene practices such as handwashing due } \\
\text { to survival of the virus on surfaces. }\end{array}$ \\
\hline 24 & $\begin{array}{l}\text { SARS Transmission, Risk Factors, } \\
\text { and Prevention in Hong Kong }\end{array}$ & $\begin{array}{l}\text { Emerging Infectious } \\
\text { Diseases }\end{array}$ & April 2004 & $\mathrm{~A}, \mathrm{~B}, \mathrm{G}$ & $\begin{array}{l}\text { Level 3b: A case-control study to } \\
\text { compare SARS case-patients with } \\
\text { undefined sources of infection with } \\
\text { community controls }\end{array}$ & $\begin{array}{l}\text { - Concluded that risk factors for SARS infection } \\
\text { include visiting mainland China, hospitals, and the } \\
\text { Amoy Gardens (an estate with a SARS outbreak). } \\
\text { - Indicates that frequent mask use in public venues, } \\
\text { frequent handwashing, and household disinfection } \\
\text { were prominent protective factors. }\end{array}$ \\
\hline
\end{tabular}




\begin{tabular}{|c|c|c|c|c|c|c|}
\hline 25 & $\begin{array}{l}\text { Respiratory Infections } \\
\text { SARS Ouring } \\
2003\end{array}$ & $\begin{array}{l}\text { Emerging Infectious } \\
\text { Diseases }\end{array}$ & $\begin{array}{l}\text { November } \\
2005\end{array}$ & $\mathrm{~A}, \mathrm{~B}, \mathrm{D}, \mathrm{G}$ & $\begin{array}{l}\text { Level 4: A cross-sectional study to } \\
\text { compare the proportion of respiratory } \\
\text { virus positive specimens in } 2003 \text { and } \\
\text { those from } 1998 \text { to } 2002\end{array}$ & $\begin{array}{l}\text { - No direct causal relationship was established. } \\
\text { - However, the study suggests a positive association } \\
\text { between reduced influenza/respiratory infection } \\
\text { incidence and population-based hygienic measures } \\
\text { including face mask wearing, hand washing after } \\
\text { contact with potentially contaminated objects, using } \\
\text { soap for handwashing, mouth covering when } \\
\text { sneezing or coughing, and household disinfection. }\end{array}$ \\
\hline 26 & $\begin{array}{l}\text { Controlling the Novel A (H1N1) } \\
\text { Influenza Virus: Don't Touch } \\
\text { Your Face! }\end{array}$ & $\begin{array}{l}\text { The Journal of } \\
\text { Hospital Infection }\end{array}$ & $\begin{array}{l}\text { November } \\
2009\end{array}$ & $\mathrm{~A}, \mathrm{C}$ & $\begin{array}{l}\text { Level 5: A letter to the editor on a } \\
\text { study of surface swab specimens from } \\
\text { patients with confirmed influenza A }\end{array}$ & $\begin{array}{l}\text { - Indicates that virus strains of influenza A are found } \\
\text { in surfaces such as bed rails, walls, and sofas. } \\
\text { - Further implies the importance of hand hygiene, } \\
\text { droplet and contact precautions, and behavioural } \\
\text { conditioning such as avoiding touching of the nose, } \\
\text { eye or mouth touching to prevent and control } \\
\text { influenza. }\end{array}$ \\
\hline 27 & Stopping the Spread of COVID-19 & $\begin{array}{l}\text { Journal of the } \\
\text { American Medical } \\
\text { Association }\end{array}$ & March 2020 & $\mathrm{~A}, \mathrm{C}, \mathrm{D}, \mathrm{G}, \mathrm{I}$ & $\begin{array}{l}\text { Level 5: A set of guidelines with } \\
\text { potential measures to stop the spread } \\
\text { of COVID-19 }\end{array}$ & $\begin{array}{l}\text { - Different methods of infection prevention including } \\
\text { hand hygiene, social distancing, household } \\
\text { disinfection, and general personal hygiene are } \\
\text { suggested. }\end{array}$ \\
\hline 28 & $\begin{array}{l}\text { Prevention of Coronavirus Disease } \\
2019 \text { (COVID-19) }\end{array}$ & $\begin{array}{l}\text { Hong Kong Centre for } \\
\text { Health Protection }\end{array}$ & May 2020 & $\begin{array}{l}\text { A, B, C, D, } \\
\text { F, G, I, J }\end{array}$ & $\begin{array}{l}\text { Level 5: A set of guidelines with } \\
\text { information related to COVID-19 } \\
\text { such as prevention suggestions and } \\
\text { clinical features of the coronavirus. }\end{array}$ & $\begin{array}{l}\text { - Prevention advice such as mask wearing, avoidance } \\
\text { of face touching, covering mouth and nose, putting } \\
\text { the toilet lid down when flushing, and general travel } \\
\text { advice is suggested. }\end{array}$ \\
\hline 29 & $\begin{array}{l}\text { Fact Sheet for SARS Patients and } \\
\text { Their Close Contact }\end{array}$ & $\begin{array}{l}\text { Centres for Disease } \\
\text { Control and } \\
\text { Prevention }\end{array}$ & 2003 & $\begin{array}{l}\text { A, B, C, D, } \\
\text { E, F, H, I, J }\end{array}$ & $\begin{array}{l}\text { Level 5: A set of guidelines with } \\
\text { information related to SARS such as } \\
\text { symptoms, mode of transmission, and } \\
\text { prevention measures }\end{array}$ & $\begin{array}{l}\text { - Personal protection measures, such as the avoidance } \\
\text { of silverware sharing, handwashing and covering } \\
\text { mouth and nose when coughing or sneezing, are } \\
\text { recommended. }\end{array}$ \\
\hline 30 & $\begin{array}{l}\text { WHO Guidelines on Hand } \\
\text { Hygiene in Health Care }\end{array}$ & WHO & 2009 & A & $\begin{array}{l}\text { Level 5: An extensive evidence-based } \\
\text { guideline on the practice and science } \\
\text { behind handwashing }\end{array}$ & $\begin{array}{l}\text { - Extensive findings on best handwashing practice and } \\
\text { efficacy of soap-based washing and alcohol against } \\
\text { enveloped viruses. }\end{array}$ \\
\hline 31 & $\begin{array}{l}\text { Simplifying the World Health } \\
\text { Organization Protocol: } 3 \text { Steps } \\
\text { Versus } 6 \text { Steps for Performance of } \\
\text { Hand Hygiene in a Cluster- } \\
\text { randomized Trial }\end{array}$ & $\begin{array}{l}\text { Clinical Infectious } \\
\text { Diseases }\end{array}$ & $\begin{array}{l}\text { August } \\
2019\end{array}$ & A & $\begin{array}{l}\text { Level 1b: A cluster-randomized trial } \\
\text { assigning 3-step vs. 6-step } \\
\text { handwashing protocol }\end{array}$ & $\begin{array}{l}\text { - Findings suggest that both significantly reduced the } \\
\text { bacterial colony (with no significant difference } \\
\text { between the two) but that the 3-step guidelines had } \\
\text { higher compliance. } \\
\text { Quantity of steps are not of great concern as long as } \\
\text { areas are covered. }\end{array}$ \\
\hline
\end{tabular}




\begin{tabular}{|c|c|c|c|c|c|c|}
\hline 32 & $\begin{array}{l}\text { The Common Missed } \\
\text { Handwashing Instances and Areas } \\
\text { after } 15 \square \text { Years of Hand-Hygiene } \\
\text { Education }\end{array}$ & $\begin{array}{l}\text { Journal of } \\
\text { Environmental and } \\
\text { Public Health }\end{array}$ & $\begin{array}{l}\text { August } \\
2019\end{array}$ & A & $\begin{array}{l}\text { Level 4: A cross-sectional study } \\
\text { looking at a cohort in Hong Kong and } \\
\text { their handwashing and hand hygiene } \\
\text { practices }\end{array}$ & $\begin{array}{l}\text { - Indicates several areas of the hands which are } \\
\text { commonly missed, as well as occasions during } \\
\text { which handwashing should be performed. } \\
\text { - Relationship between age or education and hand } \\
\text { hygiene practice is indicated. }\end{array}$ \\
\hline 33 & $\begin{array}{l}\text { Hygiene and Health: Systematic } \\
\text { Review of Handwashing Practices } \\
\text { Worldwide and Update of Health } \\
\text { Effects }\end{array}$ & $\begin{array}{l}\text { Tropical Medicine and } \\
\text { International Health }\end{array}$ & May 2014 & $\mathrm{~A}$ & $\begin{array}{l}\text { Level 1a: A systematic review of } \\
\text { RCT's and quasi-randomised trials } \\
\text { (+others). Studies observed rates of } \\
\text { handwashing with soap in various } \\
\text { populations and scenarios }\end{array}$ & $\begin{array}{l}\text { - Significant global problem regarding poor practice } \\
\text { of handwashing after contact with excrete is found. }\end{array}$ \\
\hline 34 & $\begin{array}{l}\text { Assessment of Hand Hygiene } \\
\text { Techniques Using the World } \\
\text { Health Organization's Six Steps }\end{array}$ & $\begin{array}{l}\text { Journal of Infection } \\
\text { and Public Health }\end{array}$ & Dec 2015 & A & $\begin{array}{l}\text { Level 2b: An individual cohort study } \\
\text { observing hand hygiene techniques } \\
\text { over a period of } 5 \text { months }\end{array}$ & $\begin{array}{l}\text { - Certain areas of the hand achieved lower areas of } \\
\text { compliance during handwashing. }\end{array}$ \\
\hline 35 & $\begin{array}{l}\text { Bacteriological Aspects of Hand } \\
\text { Washing: A Key for Health } \\
\text { Promotion and Infections Control }\end{array}$ & $\begin{array}{l}\text { International Journal } \\
\text { of Preventative } \\
\text { Medicine }\end{array}$ & March 2017 & A & $\begin{array}{l}\text { Level 3a: A sSystematic review of } \\
\text { case control studies }\end{array}$ & $\begin{array}{l}\text { - Handwashing can reduce infectious agent's } \\
\text { transmission in the community and healthcare } \\
\text { settings. }\end{array}$ \\
\hline 36 & $\begin{array}{l}\text { Coronavirus Disease (COVID-19) } \\
\text { Advice for the Public }\end{array}$ & WHO & April 2020 & $\mathrm{~A}, \mathrm{~B}, \mathrm{C}, \mathrm{D}, \mathrm{I}$ & $\begin{array}{l}\text { Level 5: Expert opinion on personal } \\
\text { protection from COVID-19 such as } \\
\text { safe use of alcohol-based hand } \\
\text { sanitizers }\end{array}$ & $\begin{array}{l}\text { - Informs the public of the importance of actions such } \\
\text { as regular handwashing with soap and water, } \\
\text { cleaning hands with alcohol-based rub, social } \\
\text { distancing, avoiding crowds, avoid eye, nose, mouth } \\
\text { touching, covering mouth and nose, staying home, } \\
\text { and health-seeking behaviour under the pandemic. } \\
\text { - Precautions on alcohol-based hand sanitizer use is } \\
\text { also mentioned. }\end{array}$ \\
\hline 37 & How to Protect Yourself \& Others & $\begin{array}{l}\text { Centres for Disease } \\
\text { Control and } \\
\text { Prevention }\end{array}$ & April 2020 & $\mathrm{~A}, \mathrm{~B}, \mathrm{D}, \mathrm{G}, \mathrm{I}$ & $\begin{array}{l}\text { Level 5: Expert opinion on how } \\
\text { COVID-19 spreads and personal } \\
\text { protection measures for COVID-19 }\end{array}$ & $\begin{array}{l}\text { - Informs the public of person-to-person spread of the } \\
\text { virus, the lack of vaccine to prevent COVID-19, and } \\
\text { the importance of actions such as regular } \\
\text { handwashing with soap and water, avoiding close } \\
\text { contact, covering mouse and nose with a cloth face } \\
\text { cover, covering coughs and sneezes, as well as } \\
\text { cleaning and disinfecting frequently touched surfaces } \\
\text { and households under the pandemic. }\end{array}$ \\
\hline 38 & $\begin{array}{l}\text { Hand Hygiene and the Novel } \\
\text { Coronavirus Pandemic: The Role } \\
\text { of Healthcare Workers }\end{array}$ & $\begin{array}{l}\text { The Journal of } \\
\text { Hospital Infection }\end{array}$ & March 2020 & A & $\begin{array}{l}\text { Level 5: Expert opinion on the } \\
\text { importance of practicing respiratory } \\
\text { and hand hygiene, as well as using } \\
\text { personal protective equipment in } \\
\text { healthcare settings }\end{array}$ & $\begin{array}{l}\text { - Details the role of healthcare workers, nurses and } \\
\text { midwives in providing primary point of care in } \\
\text { communities and for pregnant women respectively, } \\
\text { especially during infectious disease outbreaks. } \\
\text { - Mentions details and precautions when using } \\
\text { alcohol-based hand rubs for hand hygiene. }\end{array}$ \\
\hline
\end{tabular}




\begin{tabular}{|c|c|c|c|c|c|c|}
\hline 39 & $\begin{array}{l}\text { A Schlieren Optical Study of the } \\
\text { Human Cough With and Without } \\
\text { Wearing Masks for Aerosol } \\
\text { Infection Control }\end{array}$ & $\begin{array}{l}\text { Journal of the Royal } \\
\text { Society, Interface }\end{array}$ & $\begin{array}{l}\text { December } \\
2009\end{array}$ & $\mathrm{~B}, \mathrm{D}$ & $\begin{array}{l}\text { Level 5: A study comparing the fluid } \\
\text { dynamics of coughing with or without } \\
\text { standard surgical or N95 mask } \\
\text { wearing using video records. }\end{array}$ & $\begin{array}{l}\text { - Human coughing projects a rapid turbulent jet into } \\
\text { the surrounding air } \\
\text { - Wearing a surgical or N95 mask interrupts the } \\
\text { natural mechanism of airborne infection transmission } \\
\text { through blocking turbulent jet formation (N95 mask) } \\
\text { or redirecting the exhalant (surgical mask). }\end{array}$ \\
\hline 40 & $\begin{array}{l}\text { Respiratory Virus Shedding in } \\
\text { Exhaled Breath and Efficacy of } \\
\text { Face Masks }\end{array}$ & Nature Medicine & April 2020 & B & $\begin{array}{l}\text { Level 1b: A randomized controlled } \\
\text { trial comparing exhaled breath } \\
\text { samples (for respiratory virus } \\
\text { shedding) in mask wearing vs. non } \\
\text { mask wearing individuals }\end{array}$ & $\begin{array}{l}\text { - Surgical face masks can prevent transmission of } \\
\text { human coronaviruses and influenza viruses from } \\
\text { symptomatic individuals. } \\
\text { - Surgical face masks reduce detection of coronavirus } \\
\text { RNA in aerosols, with a trend towards reduced } \\
\text { detection of coronavirus RNA in respiratory } \\
\text { droplets. }\end{array}$ \\
\hline 41 & $\begin{array}{l}\text { Early Transmission Dynamics in } \\
\text { Wuhan, China, of Novel } \\
\text { Coronavirus-infected Pneumonia }\end{array}$ & $\begin{array}{l}\text { The New England } \\
\text { Journal of Medicine }\end{array}$ & $\begin{array}{l}\text { January } \\
2020\end{array}$ & B & $\begin{array}{l}\text { Level 4: A case series looking at } \\
\text { characteristics and illness timelines of } \\
\text { laboratory confirmed cases of } \\
\text { COVID-19 }\end{array}$ & $\begin{array}{l}\text { - Human-to-human transmission has occurred and that } \\
\text { measures must be implemented towards populations } \\
\text { at risk. }\end{array}$ \\
\hline 42 & $\begin{array}{l}\text { Contamination by Respiratory } \\
\text { Viruses on Outer Surface of } \\
\text { Medical Masks Used by Hospital } \\
\text { Healthcare Workers }\end{array}$ & $\begin{array}{l}\text { BMC Infectious } \\
\text { Diseases }\end{array}$ & June 2019 & B & $\begin{array}{l}\text { Level 1b: An individual randomised } \\
\text { controlled trial with two pilot studies } \\
\text { (cohort). Participants told to wear } \\
\text { medical masks and then masks were } \\
\text { checked for respiratory viruses on the } \\
\text { surface }\end{array}$ & $\begin{array}{l}\text { - Virus presence on the face mask was higher when } \\
\text { worn for a longer period of time (in the 6> } \\
\text { subgroup). } \\
\text { - The study concluded that because of this risk, the } \\
\text { pathogens on the outer surface may cause self- } \\
\text { contamination, with greater risk when worn for }>6 \\
\text { hours. } \\
\text { - Indications that there should be a maximum time on } \\
\text { mask usage. }\end{array}$ \\
\hline 43 & $\begin{array}{l}\text { Stability of SARS-CoV-2 in } \\
\text { different environmental conditions }\end{array}$ & The Lancet & May 2020 & $\mathrm{~B}, \mathrm{G}$ & $\begin{array}{l}\text { Level 5: An experimental study on } \\
\text { the stability of COVID-19 in different } \\
\text { induced environmental conditions } \\
\text { such as under heat stress and on } \\
\text { different surfaces }\end{array}$ & $\begin{array}{l}\text { - Infectious virus was not detected after } 5 \text { minutes } \\
\text { incubation at room temperature, wide range of } \mathrm{pH} \\
\text { stability, was found to be stable on surfaces such as } \\
\text { the outer layer of surgical masks. } \\
\text { - Virus was susceptible to disinfection methods. }\end{array}$ \\
\hline 44 & $\begin{array}{l}\text { What You Need to Know About } \\
\text { Infectious Disease }\end{array}$ & $\begin{array}{l}\text { US Institute of } \\
\text { Medicine }\end{array}$ & 2010 & C, D & $\begin{array}{l}\text { Level 5: A book that contains expert } \\
\text { opinion on infectious diseases and the } \\
\text { nature of their transmission }\end{array}$ & $\begin{array}{l}\text { - The mouth, the eyes and the nose are the body's } \\
\text { main entry points for transmittable conditions such } \\
\text { as influenza. } \\
\text { - Coughing and sneezing facilitates the spread of } \\
\text { droplet-transmittable diseases. }\end{array}$ \\
\hline 45 & $\begin{array}{l}\text { Face Touching: A Frequent Habit } \\
\text { that Has Implications for Hand } \\
\text { Hygiene }\end{array}$ & $\begin{array}{l}\text { American Journal of } \\
\text { Infection Control }\end{array}$ & $\begin{array}{l}\text { February } \\
2015\end{array}$ & C & $\begin{array}{l}\text { Level 2b: A behavioural observation } \\
\text { study of } 26 \text { participants exploring the } \\
\text { habit of face touching }\end{array}$ & $\begin{array}{l}\text { - Even amongst medical students, there was frequent } \\
\text { face touching behaviour. } \\
\text { - This indicates towards the importance of hand } \\
\text { hygiene too apart from the risk of self-inoculation } \\
\text { from face touching which needs to be elucidated. }\end{array}$ \\
\hline
\end{tabular}




\begin{tabular}{|c|c|c|c|c|c|c|}
\hline 46 & $\begin{array}{l}\text { Self-touch: Contact Durations and } \\
\text { Point of Touch of Spontaneous } \\
\text { Facial Self-touches Differ } \\
\text { Depending on Cognitive and } \\
\text { Emotional Load }\end{array}$ & $\begin{array}{l}\text { PLOS ONE } \\
\text { Medicine (Baltimore) }\end{array}$ & March 2019 & $\mathrm{C}$ & $\begin{array}{l}\text { Level 2b: A cohort study exploring } \\
\text { the behaviour of face touching and its } \\
\text { link to cognitive and emotional load }\end{array}$ & $\begin{array}{l}\text { - Results showed the both the point of touch and } \\
\text { contact durations were under influence from } \\
\text { emotional and cognitive triggers. }\end{array}$ \\
\hline 47 & $\begin{array}{l}\text { Protective Effect of Hand-washing } \\
\text { and Good Hygienic Habits against } \\
\text { Seasonal Influenza: A Case- } \\
\text { control Study }\end{array}$ & Medicine (Baltimore) & March 2016 & $\mathrm{~A}$ & $\begin{array}{l}\text { Level 3b: A single case-control study } \\
\text { testing the link between influenza } \\
\text { transmission and self-reported } \\
\text { handwashing / unhealthy hygiene } \\
\text { habits }\end{array}$ & $\begin{array}{l}\text { - Frequent handwashing and better hygiene habits } \\
\text { were associated with a reduction in the risk of } \\
\text { influenza infection. }\end{array}$ \\
\hline 48 & $\begin{array}{l}\text { Hand Hygiene and Risk of } \\
\text { Influenza Virus Infections in the } \\
\text { Community: A Systematic Review } \\
\text { and Meta-analysis }\end{array}$ & $\begin{array}{l}\text { Epidemiology \& } \\
\text { Infection }\end{array}$ & May 2014 & $\mathrm{~A}$ & $\begin{array}{l}\text { Level 1a: A systematic review of } 10 \\
\text { randomized controlled trials aiming } \\
\text { to evaluate the efficacy of hand } \\
\text { hygiene measures against the } \\
\text { reduction of influenza transmission }\end{array}$ & $\begin{array}{l}\text { - Findings suggested that while hand washing may be } \\
\text { effective (modest efficacy) against one mode of } \\
\text { transmission i.e. contact, further measures may also } \\
\text { be important to control influenza transmission, for } \\
\text { example face masks. }\end{array}$ \\
\hline 49 & $\begin{array}{l}\text { Effect of Washing Hands with } \\
\text { Soap on Diarrhoea risk in the } \\
\text { community: A Systematic Review }\end{array}$ & $\begin{array}{l}\text { Cochrane Database of } \\
\text { Systematic Reviews }\end{array}$ & $\begin{array}{l}\text { September } \\
2015\end{array}$ & $\mathrm{~A}$ & $\begin{array}{l}\text { Level 1a: A systematic review of } 22 \\
\text { randomised controlled trials to } \\
\text { compare diarrhoea occurrence in } \\
\text { children and adults with or without } \\
\text { handwashing measures }\end{array}$ & $\begin{array}{l}\text { - Handwashing measures result in diarrhoea episode } \\
\text { reductions in child day-care centres in high-income } \\
\text { countries as well as communities in low- and } \\
\text { middle-income countries. } \\
\text { - It is a challenge to encourage the habitual } \\
\text { maintenance of handwashing habits in people in the } \\
\text { long-term. }\end{array}$ \\
\hline 50 & $\begin{array}{l}\text { Hand Washing Promotion for } \\
\text { Preventing Diarrhoea }\end{array}$ & $\begin{array}{l}\text { Cochrane Systematic } \\
\text { Review }\end{array}$ & $\begin{array}{l}\text { September } \\
2015\end{array}$ & $\mathrm{~A}$ & $\begin{array}{l}\text { Level 1a: A systematic review of } \\
\text { randomized controlled trials and } \\
\text { cluster RCT's to compare the effects } \\
\text { of measures associated with } \\
\text { handwashing on the occurrence of } \\
\text { diarrhoea episodes in children }\end{array}$ & $\begin{array}{l}\text { - Hand washing most likely reduces diarrhoea } \\
\text { episodes in certain communities, as per the study's } \\
\text { findings. } \\
\text { - There may be lack of understanding on how to help } \\
\text { people maintain habits related to handwashing in the } \\
\text { long term. }\end{array}$ \\
\hline 51 & $\begin{array}{l}\text { Reducing the Risk of Infection: } \\
\text { Hand Washing Technique }\end{array}$ & $\begin{array}{l}\text { Community Eye } \\
\text { Health }\end{array}$ & March 2008 & $\mathrm{~A}$ & $\begin{array}{l}\text { Level 5: Expert guidance on } \\
\text { components of a good handwashing } \\
\text { route }\end{array}$ & $\begin{array}{l}\text { Indicates that handwashing is critical to infection } \\
\text { control and that there may be inadequate awareness on } \\
\text { importance of handwashing techniques, which may be } \\
\text { impeding effectiveness. }\end{array}$ \\
\hline
\end{tabular}




\begin{tabular}{|c|c|c|c|c|c|c|}
\hline 52 & $\begin{array}{l}\text { The Effectiveness of Hand } \\
\text { Hygiene Procedures in Reducing } \\
\text { the Risks of Infections in Home } \\
\text { and Community Settings Including } \\
\text { Handwashing and Alcohol-based } \\
\text { Hand Sanitizers }\end{array}$ & $\begin{array}{l}\text { American Journal of } \\
\text { Infection Control }\end{array}$ & $\begin{array}{l}\text { December } \\
2007\end{array}$ & A & $\begin{array}{l}\text { Level 5: A report reviewing the } \\
\text { evidence on hand hygiene and its link } \\
\text { to infectious disease transmissions }\end{array}$ & $\begin{array}{l}\text { - Hand hygiene is a significant component of good } \\
\text { hygiene in households and communities and has } \\
\text { significant benefit towards the reduction of infection } \\
\text { transmission, including respiratory tract infections. } \\
\text { - Further conclusion that hand hygiene's impact } \\
\text { towards infectious disease reduction can be enhanced } \\
\text { by improved persuasion of community handwashing } \\
\text { (properly and at the right times) and that hand } \\
\text { hygiene promotion should come hand in hand with } \\
\text { other aspects of hygiene and associated education. }\end{array}$ \\
\hline 53 & $\begin{array}{l}\text { Effectiveness of Commercial Face } \\
\text { Masks to Reduce Personal PM } \\
\text { Exposure. }\end{array}$ & $\begin{array}{l}\text { Science of the Total } \\
\text { Environment }\end{array}$ & $\begin{array}{l}\text { September } \\
2018\end{array}$ & B & $\begin{array}{l}\text { Level 5: A model-based study } \\
\text { evaluating the efficacy of face mask } \\
\text { respirators towards the reduction of } \\
\text { airborne particle exposure and } \\
\text { subsequent pollutant exposure }\end{array}$ & $\begin{array}{l}\text { - Facemasks reduce exposure to urban pollution. } \\
\text { The efficacy of available face masks can vary in } \\
\text { achieving exposure reduction to urban pollution. }\end{array}$ \\
\hline 54 & $\begin{array}{l}\text { Exploring Motivations behind } \\
\text { Pollution-mask Use in a Sample of } \\
\text { Young Adults in Urban China }\end{array}$ & $\begin{array}{l}\text { Globalization and } \\
\text { Health }\end{array}$ & $\begin{array}{l}\text { December } \\
2018\end{array}$ & B & $\begin{array}{l}\text { Level 4: A cross-sectional survey } \\
\text { exploring the role of socio-cognitive } \\
\text { factors in affecting the decision of } \\
\text { wearing a pollution mask in the } \\
\text { context of young educated people }\end{array}$ & $\begin{array}{l}\text { - Mask wearing practice is influenced by various } \\
\text { reasons including but not limited to level of } \\
\text { education, social norms, self-efficacy, attitudes and } \\
\text { past behaviour. } \\
\text { - The conclusion indicates the need towards changing } \\
\text { the social perception towards mask-wearing practice. }\end{array}$ \\
\hline 55 & WHO $\mid$ Air Pollution & WHO & N/A & $\mathrm{B}, \mathrm{I}$ & $\begin{array}{l}\text { Level 5: A collection of resources } \\
\text { including global data on air pollution } \\
\text { and subsequent protective measures }\end{array}$ & $\begin{array}{l}\text { - Demonstrates that } 9 / 10 \text { people breathe air containing } \\
\text { high levels of pollutants and concludes these as risk } \\
\text { factors towards health. }\end{array}$ \\
\hline 56 & $\begin{array}{l}\text { Air Pollution: A Smoking Gun for } \\
\text { Cancer }\end{array}$ & $\begin{array}{l}\text { Chinese Journal of } \\
\text { Cancer }\end{array}$ & April 2014 & B & $\begin{array}{l}\text { Level 5: A review on various articles } \\
\text { to discuss key questions surrounding } \\
\text { the link of air pollution with cancer } \\
\text { incidence, with a focus on China }\end{array}$ & $\begin{array}{l}\text { - Air pollution was and is a risk for cancer; makes } \\
\text { final recommendations such as the need for personal } \\
\text { pollution monitoring devices as well as increase } \\
\text { international collaborations upon this matter. }\end{array}$ \\
\hline 57 & $\begin{array}{l}\text { A Retrospective Approach to } \\
\text { Assess Human Health Risks } \\
\text { Associated with Growing Air } \\
\text { Pollution in Urbanized Area of } \\
\text { Thar Desert, Western Rajasthan, } \\
\text { India }\end{array}$ & $\begin{array}{l}\text { Journal of } \\
\text { Environmental Health } \\
\text { Science and } \\
\text { Engineering. }\end{array}$ & $\begin{array}{l}\text { January } \\
2014\end{array}$ & B & $\begin{array}{l}\text { Level 2b: A retrospective cohort } \\
\text { study looking into the air pollution } \\
\text { measures and associated statistics on } \\
\text { disease burden }\end{array}$ & $\begin{array}{l}\text { - Environmental burden of disease and association to } \\
\text { air pollution is a main concern in the fast-developing } \\
\text { areas of India. } \\
\text { - Households exposed to high vehicle-caused pollution } \\
\text { presented with greater prevalence of respiratory } \\
\text { diseases for example. }\end{array}$ \\
\hline 58 & Saliva and Viral Infections & Periodontology 2000 & $\begin{array}{l}\text { December } \\
2015\end{array}$ & $\mathrm{C}, \mathrm{E}$ & $\begin{array}{l}\text { Level 5: A review on various } \\
\text { publications associated with viral } \\
\text { infections via the oral cavity and } \\
\text { discussing assays }\end{array}$ & $\begin{array}{l}\text { - Regarding saliva and its role in viral infections, it } \\
\text { indicates that it plays a key role and that the mouth } \\
\text { and eye are common sites for viral entry. } \\
\text { - Conclusion that the oral cavity is a significant area } \\
\text { for infection as well as virus transmission. }\end{array}$ \\
\hline
\end{tabular}




\begin{tabular}{|c|c|c|c|c|c|c|}
\hline 59 & $\begin{array}{l}\text { Detection of Bacterial Pathogens } \\
\text { in the Hands of Rural School } \\
\text { Children Across Different Age } \\
\text { Groups and Emphasizing the } \\
\text { Importance of Hand Wash }\end{array}$ & $\begin{array}{l}\text { Journal of Preventive } \\
\text { Medicine and Hygiene }\end{array}$ & June 2019 & $\mathrm{C}$ & $\begin{array}{l}\text { Level 4: A cross-sectional } \\
\text { observational study on hand } \\
\text { pathogens in } 200 \text { rural school } \\
\text { children }\end{array}$ & $\begin{array}{l}\text { - Concluded that in this rural-based cohort, the hands } \\
\text { of the children were harbouring various, potentially } \\
\text { fatal, pathogenic organisms and could thus be a } \\
\text { major source of infection. } \\
\text { - Indication towards the importance of hand washing } \\
\text { and the need to provide materials (which are not } \\
\text { available to these groups) in order to reduce spread } \\
\text { of infection which is otherwise reducible via hand } \\
\text { hygiene. }\end{array}$ \\
\hline 60 & $\begin{array}{l}\text { Viricidal Activity of World Health } \\
\text { Organization-recommended } \\
\text { Formulations Against Enveloped } \\
\text { Viruses, Including Zika, Ebola, } \\
\text { and Emerging Coronaviruses }\end{array}$ & $\begin{array}{l}\text { The Journal of } \\
\text { Infectious Diseases }\end{array}$ & March 2017 & $\mathrm{~A}$ & $\begin{array}{l}\text { Level 5: An in vitro experiment } \\
\text { testing the efficacy of two WHO } \\
\text { recommended alcohol-based } \\
\text { formulations against different } \\
\text { enveloped viruses }\end{array}$ & $\begin{array}{l}\text { - WHO recommended alcohol-based formulations } \\
\text { worked against the different enveloped viruses and } \\
\text { the viricidal effect was strong. }\end{array}$ \\
\hline 61 & $\begin{array}{l}\text { Effect of Handwashing on Child } \\
\text { Health: A Randomised Controlled } \\
\text { Trial }\end{array}$ & The Lancet & July 2005 & $\mathrm{~A}$ & $\begin{array}{l}\text { Level 1b: A randomised controlled } \\
\text { trial randomly assigning of } \\
\text { handwashing promotion to one group } \\
\text { and no promotion to the other vs. } \\
\text { randomised controls. Outcomes } \\
\text { explored included diarrhoea and acute } \\
\text { respiratory tract infections. }\end{array}$ & $\begin{array}{l}\text { - Study found that households receiving plain soap } \\
\text { with handwashing promotion had lower incidence of } \\
\text { the studied infections and that there was not much } \\
\text { difference between plain vs. antibacterial soap. } \\
\text { - Indicates the importance of such programs and } \\
\text { distribution of soap. } \\
\text { - Concluding that handwashing was effective in } \\
\text { preventing conditions like diarrhoea and respiratory } \\
\text { disease. }\end{array}$ \\
\hline 62 & $\begin{array}{l}\text { Hand Cleaning with Ash for } \\
\text { Reducing the Spread of Viral and } \\
\text { Bacterial Infections: A Rapid } \\
\text { Review }\end{array}$ & Cochrane & April 2020 & A & $\begin{array}{l}\text { Level 5: A systematic review using } \\
\text { different types of studies to assess the } \\
\text { advantages and disadvantages of ash } \\
\text { as an alternative to soap or other } \\
\text { materials against viruses and bacteria }\end{array}$ & $\begin{array}{l}\text { - Studies were unreliable and rarely adequate } \\
\text { examined rate of infection. Therefore, ash could not } \\
\text { be concluded as a suitable alternative. }\end{array}$ \\
\hline 63 & $\begin{array}{l}\text { Comparison of Four Methods of } \\
\text { Hand Washing in Situations of } \\
\text { Inadequate Water Supply }\end{array}$ & $\begin{array}{l}\text { West African Journal } \\
\text { of Medicine }\end{array}$ & $\begin{array}{l}\text { January } \\
2008\end{array}$ & $\mathrm{~A}$ & $\begin{array}{l}\text { Level } 1 \mathrm{~b} \text { : A randomised controlled } \\
\text { trial comparing different methods of } \\
\text { hand washing developed for use in } \\
\text { developing countries }\end{array}$ & $\begin{array}{l}\text { - The 'Elbow way' of handwashing is the gold } \\
\text { standard with no evidence of post-contamination. } \\
\text { - Bucket and bowl as well as the single-bowl method } \\
\text { result in cross contamination. }\end{array}$ \\
\hline 64 & $\begin{array}{l}\text { Testing the Efficacy of Homemade } \\
\text { Masks: Would They Protect in an } \\
\text { Influenza Pandemic? }\end{array}$ & $\begin{array}{l}\text { Disaster Medicine and } \\
\text { Public Health } \\
\text { Preparedness }\end{array}$ & $\begin{array}{l}\text { August } \\
2013\end{array}$ & $\mathrm{~A}$ & $\begin{array}{l}\text { Level 1b: A randomised controlled } \\
\text { trial on the effectiveness of different } \\
\text { household materials in making } \\
\text { homemade masks as an alternative to } \\
\text { commercial face masks }\end{array}$ & $\begin{array}{l}\text { - While a homemade mask also results in a decrease in } \\
\text { number of microorganisms expelled by volunteers, a } \\
\text { homemade mask is significantly less effective than } \\
\text { surgical masks and should only be a last resort for } \\
\text { droplet transmission prevention. }\end{array}$ \\
\hline
\end{tabular}




\begin{tabular}{|c|c|c|c|c|c|c|}
\hline 65 & $\begin{array}{l}\text { Aerosol Filtration Efficiency of } \\
\text { Common Fabrics Used in } \\
\text { Respiratory Cloth Masks }\end{array}$ & $\begin{array}{l}\text { American Chemical } \\
\text { Society Nano }\end{array}$ & April 2020 & B & $\begin{array}{l}\text { Level 5: An experimental approach to } \\
\text { assess common fabrics (such as } \\
\text { cotton) and their filtration efficiencies }\end{array}$ & $\begin{array}{l}\text { - Found that in general, cloth masks could potentially } \\
\text { offer notable protection against transmission of } \\
\text { particles which have sizes within the aerosol range. } \\
\text { - Further findings on factors limiting effectiveness } \\
\text { such as leakages due to fitting issues and influence } \\
\text { of factors such as humidity, repeated use and } \\
\text { washing. }\end{array}$ \\
\hline 66 & $\begin{array}{l}\text { Handwashing: Clean Hands Save } \\
\text { Lives }\end{array}$ & $\begin{array}{l}\text { Journal of Consumer } \\
\text { Health on the Internet }\end{array}$ & $\begin{array}{l}\text { February } \\
2020\end{array}$ & $\mathrm{~A}$ & $\begin{array}{l}\text { Level 5: An expert collection of } \\
\text { information on handwashing as well } \\
\text { as the explanations behind it }\end{array}$ & $\begin{array}{l}\text { Collects the key points on handwashing as well as the } \\
\text { science behind the measure to ultimate make } \\
\text { recommendations regarding when to wash and how to } \\
\text { wash. }\end{array}$ \\
\hline 67 & $\begin{array}{l}\text { Effectiveness of Handwashing in } \\
\text { Preventing SARS: A Review }\end{array}$ & $\begin{array}{l}\text { Tropical Medicine and } \\
\text { International Health }\end{array}$ & $\begin{array}{l}\text { September } \\
2006\end{array}$ & $\mathrm{~A}$ & $\begin{array}{l}\text { Level 3a: A systematic review of } \\
\text { case-control studies to evaluate } \\
\text { effectiveness of handwashing in } \\
\text { protecting against SARS transmission }\end{array}$ & $\begin{array}{l}\text { - Only three studies out of the ten reviewed were } \\
\text { statistically significant. } \\
\text { - While there is no conclusive evidence on the } \\
\text { effectiveness of handwashing, this measure remains } \\
\text { suggestive to protect against SARS transmission in } \\
\text { the community and healthcare settings. }\end{array}$ \\
\hline 68 & $\begin{array}{l}\text { Efficacy of Handwashing Duration } \\
\text { and Drying Methods }\end{array}$ & $\begin{array}{l}\text { International } \\
\text { Association for Food } \\
\text { Protection }\end{array}$ & July 2012 & A & $\begin{array}{l}\text { Level 1b: A randomised controlled } \\
\text { trial on the impact of soap or plain } \\
\text { water, duration of practice, presence } \\
\text { of debris and drying method on } \\
\text { microorganism removal from hands } \\
\text { through handwashing }\end{array}$ & $\begin{array}{l}\text { - The use of soap, longer duration of handwashing, } \\
\text { and towel drying significantly remove } \\
\text { microorganisms compared to plain water, shorter } \\
\text { duration and air drying respectively. } \\
\text { - Towel drying presented with a greater person-to- } \\
\text { person variability. Presence of food debris made } \\
\text { handwashing less effective. }\end{array}$ \\
\hline 69 & $\begin{array}{l}\text { Risk Factors for SARS among } \\
\text { Persons without Known Contact } \\
\text { with SARS Patients, Beijing, } \\
\text { China }\end{array}$ & $\begin{array}{l}\text { Emerging Infectious } \\
\text { Diseases }\end{array}$ & $\begin{array}{l}\text { February } \\
2004\end{array}$ & $\mathrm{~B}$ & $\begin{array}{l}\text { Level 3b: An individual case-control } \\
\text { study to compare unlinked probable } \\
\text { SARS patients with other } \\
\text { community-based controls }\end{array}$ & $\begin{array}{l}\text { - Concluded that chronic medical conditions, visit to } \\
\text { fever clinics, eating outside home, and frequent taxi } \\
\text { taking were risk factors in case patients. } \\
\text { - Also indicated that mask wearing is strongly } \\
\text { protective in reducing risk for SARS. }\end{array}$ \\
\hline 70 & $\begin{array}{l}\text { Effectiveness of Surgical and } \\
\text { Cotton Masks in Blocking SARS- } \\
\text { CoV-2: A Controlled Comparison } \\
\text { in } 4 \text { Patients }\end{array}$ & $\begin{array}{l}\text { Annals of Internal } \\
\text { Medicine }\end{array}$ & April 2020 & $\mathrm{~B}$ & $\begin{array}{l}\text { Level 1b: A randomised controlled } \\
\text { trial to compare the effectiveness of } \\
\text { surgical and cotton masks in filtering } \\
\text { SARS-CoV-2 }\end{array}$ & $\begin{array}{l}\text { - Both surgical and cotton masks are potentially } \\
\text { ineffective in the prevention of SARS-CoV-2 from } \\
\text { patient coughs to the environment and external mask } \\
\text { surface. }\end{array}$ \\
\hline
\end{tabular}




\begin{tabular}{|c|c|c|c|c|c|c|}
\hline 71 & $\begin{array}{l}\text { Mass Masking in the COVID-19 } \\
\text { Epidemic: People Need Guidance }\end{array}$ & The Lancet & March 2020 & B & $\begin{array}{l}\text { Level 5: Expert opinion on the } \\
\text { importance of plans for mass masking } \\
\text { adoptions in the community under the } \\
\text { emergence of COVID-19 }\end{array}$ & $\begin{array}{l}\text { - Indicates that compulsory social distancing and mass } \\
\text { masking are the measures that appear to be } \\
\text { temporarily successful in China. } \\
\text { - Expresses that while the efficacy of mask wearing } \\
\text { may be lacking evidence, absence of evidence should } \\
\text { not be equated to inefficacy, especially in the context } \\
\text { of COVID-19 with limited alternatives. Suggests that } \\
\text { masking can intercept the transmission link and. } \\
\text { Urges governments and health authorities to make } \\
\text { advance preparations on mass masking locally to } \\
\text { prepare for challenges ahead. }\end{array}$ \\
\hline 72 & $\begin{array}{l}\text { The Role of Community-wide } \\
\text { Wearing of Face Mask for Control } \\
\text { of Coronavirus Disease } 2019 \\
\text { (COVID-19) Epidemic due to } \\
\text { SARS-CoV-2 }\end{array}$ & Journal of Infection & April 2020 & B & $\begin{array}{l}\text { Level 4: A cross-sectional } \\
\text { observational study with } \\
\text { epidemiological analysis on COVID- } \\
19 \text { confirmed cases in Hong Kong } \\
\text { with community-wide masking and } \\
\text { that of non-mask-wearing countries }\end{array}$ & $\begin{array}{l}\text { - Community-wide mask wearing may potentially } \\
\text { improve COVID-19 control through reducing } \\
\text { infected saliva and respiratory droplet emission from } \\
\text { infected individuals. }\end{array}$ \\
\hline 73 & $\begin{array}{ll}\text { WHO Coronavirus } & \text { Disease } \\
\text { (COVID-19) Dashboard } & \end{array}$ & WHO & N/A & B & $\begin{array}{l}\text { Others: Provides latest figures on } \\
\text { COVID-19 new cases, confirmed } \\
\text { cases, and deaths in a timely manner }\end{array}$ & - Latest figure updates on COVID-19. \\
\hline 74 & $\begin{array}{l}\text { To Mask or Not to Mask: } \\
\text { Modelling the Potential for Face } \\
\text { Mask Use by the General Public to } \\
\text { Curtail the COVID-19 Pandemic }\end{array}$ & $\begin{array}{l}\text { Infectious Disease } \\
\text { Modelling }\end{array}$ & April 2020 & $\mathrm{~B}, \mathrm{I}$ & $\begin{array}{l}\text { Level 5: A study on hHypothetical } \\
\text { mask adoption scenarios with } \\
\text { proposed model simulations are used } \\
\text { to evaluatestudy the effect of mask } \\
\text { wearing on mortality reduction and } \\
\text { reduced COVID-19 transmission }\end{array}$ & $\begin{array}{l}\text { - Mask wearing by the general public may be } \\
\text { potentially effective in reducing community } \\
\text { transmission and relieving the pandemic burden. } \\
\text { - Suggests that the community-wide benefits are likely } \\
\text { to be the most significant when face masks are used } \\
\text { with other protection practices such as social } \\
\text { distancing, and when adoption is nearly universal } \\
\text { with a high compliance. }\end{array}$ \\
\hline 75 & $\begin{array}{l}\text { Persistence of Coronaviruses on } \\
\text { Inanimate Surfaces and Their } \\
\text { Inactivation with Biocidal Agents }\end{array}$ & $\begin{array}{l}\text { The Journal of } \\
\text { Hospital Infection }\end{array}$ & March 2020 & $\mathrm{C}, \mathrm{G}$ & $\begin{array}{l}\text { Level 5: A literature review on the } \\
\text { persistence of coronaviruses on } \\
\text { inanimate surfaces and chemical } \\
\text { disinfection strategies for biocidal } \\
\text { agent inactivation }\end{array}$ & $\begin{array}{l}\text { - Human coronaviruses can persist on inanimate } \\
\text { surfaces like metal, glass or plastic for up to } 9 \text { days. } \\
\text { - They can be efficiently inactivated using biocidal } \\
\text { agents. } \\
\text { - Early containment and prevention of further } \\
\text { COVID-19 spread is crucial. }\end{array}$ \\
\hline 76 & 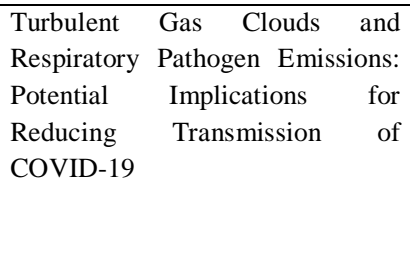 & $\begin{array}{l}\text { Journal of the } \\
\text { American Medical } \\
\text { Association JAMA }\end{array}$ & March 2020 & $\mathrm{D}, \mathrm{I}$ & $\begin{array}{l}\text { Level 5: Expert opinion on turbulent } \\
\text { gas clouds and respiratory pathogen } \\
\text { emissions }\end{array}$ & $\begin{array}{l}\text { - Suggests that pathogen-bearing droplets from a } \\
\text { human sneeze can travel up to } 7-8 \text { metres under } \\
\text { forward momentum of the gas cloud. } \\
\text { - Indicates implications for prevention and precaution } \\
\text { in COVID-19, including maintenance of distance } \\
\text { away from infected individuals in healthcare } \\
\text { settings. }\end{array}$ \\
\hline
\end{tabular}




\begin{tabular}{|c|c|c|c|c|c|c|}
\hline 77 & $\begin{array}{l}\text { Human Saliva: Non-Invasive Fluid } \\
\text { for Detecting Novel Coronavirus } \\
(2019-\mathrm{nCoV})\end{array}$ & $\begin{array}{l}\text { International Journal } \\
\text { of Environmental } \\
\text { Research and Public } \\
\text { Health }\end{array}$ & $\begin{array}{l}\text { March } \\
2020\end{array}$ & E, H & $\begin{array}{l}\text { Level 4: A case series on viral } \\
\text { detection in saliva samples of } \\
\text { COVID-19 patients on the first day of } \\
\text { hospitalisation }\end{array}$ & $\begin{array}{l}\text { - Indicates consistent detection of coronavirus in } \\
\text { saliva of COVID-19 patients admitted from first day } \\
\text { of hospitalization. } \\
\text { - Demonstrates advantage of saliva sampling } \\
\text { comfortability in epidemic situations such as } \\
\text { COVID-19. } \\
\text { - Suggests further investigation on human saliva } \\
\text { diagnostic capacity for coronaviruses. }\end{array}$ \\
\hline 78 & $\begin{array}{l}\text { Consistent Detection of } 2019 \\
\text { Novel Coronavirus in Saliva }\end{array}$ & $\begin{array}{l}\text { Clinical Infectious } \\
\text { Diseases }\end{array}$ & Feb 2020 & E, $\mathrm{H}$ & $\begin{array}{l}\text { Level 4: A case series on saliva viral } \\
\text { load in self-collected saliva of } \\
\text { COVID-19 patients }\end{array}$ & $\begin{array}{l}\text { - Indicates consistent detection of live virus in saliva } \\
\text { by viral culture. } \\
\text { - Suggests that saliva sampling is a promising and } \\
\text { non-invasive method with high diagnostic, } \\
\text { monitoring and infection control capacity in patients } \\
\text { with COVID-19 infection. }\end{array}$ \\
\hline 79 & $\begin{array}{l}\text { Microbiological Contamination of } \\
\text { Environments and Surfaces at } \\
\text { Commercial Restaurants }\end{array}$ & $\begin{array}{l}\text { Ciência \& Saúde } \\
\text { Coletiva }\end{array}$ & 2010 & $\mathrm{E}$ & $\begin{array}{l}\text { Level 5: A study on the levels of } \\
\text { microbiological contamination on } \\
\text { restaurant surfaces }\end{array}$ & $\begin{array}{l}\text { - Extensive contamination by bacteria was observed in } \\
\text { restaurant surfaces such as utensils, equipment, and } \\
\text { stainless-steel benches. } \\
\text { Suggests further sanitary measure to reduce risks of } \\
\text { foodborne diseases. }\end{array}$ \\
\hline 80 & $\begin{array}{l}\text { Contamination by Bacillus Cereus } \\
\text { on Equipment and Utensil } \\
\text { Surfaces in a Food and Nutrition } \\
\text { Service Unit }\end{array}$ & $\begin{array}{l}\text { Ciência \& Saúde } \\
\text { Coletiva }\end{array}$ & $\begin{array}{l}\text { September } \\
2011\end{array}$ & $\mathrm{E}$ & $\begin{array}{l}\text { Level 5: A study on the levels of } \\
\text { microbiological contamination in } \\
\text { food processing plants }\end{array}$ & $\begin{array}{l}\text { Significant contamination by bacteria was identified in } \\
\text { over } 30 \% \text { of the equipment and utensils studied in } \\
\text { food processing plants. }\end{array}$ \\
\hline 81 & $\begin{array}{l}\text { Detectable SARS-CoV-2 Viral } \\
\text { RNA in Faeces of Three Children } \\
\text { During Recovery Period of } \\
\text { COVID-19 Pneumonia }\end{array}$ & $\begin{array}{l}\text { Journal of Medical } \\
\text { Virology }\end{array}$ & March 2020 & $\mathrm{~F}$ & $\begin{array}{l}\text { Level 4: A case series in which } \\
\text { information of COVID-19 infected } \\
\text { children was collected, such as } \\
\text { clinical characteristics and chest } \\
\text { imaging }\end{array}$ & $\begin{array}{l}\text { - Concluded that SARS-CoV-2 viral RNA is } \\
\text { detectable in the faecal samples of three children } \\
\text { during their recovery from COVID-19 pneumonia. }\end{array}$ \\
\hline 82 & $\begin{array}{l}\text { CUHK Finds that the Coronavirus } \\
\text { Can Persist in Stool after Its } \\
\text { Clearance in Respiratory Tract; } \\
\text { Will Conduct Stool Test for } \\
\text { People in Quarantine Camps for } \\
\text { Early Identification }\end{array}$ & $\begin{array}{l}\text { The Chinese } \\
\text { University of Hong } \\
\text { Kong }\end{array}$ & March 2020 & $\mathrm{~F}, \mathrm{~J}$ & $\begin{array}{l}\text { Level 4: A case series on the viral } \\
\text { load of faecal samples from COVID- } \\
19 \text { patients }\end{array}$ & $\begin{array}{l}\text { - Concluded that all studied patients have COVID-19 } \\
\text { virus detected in their faecal samples. } \\
\text { - For a minority of patients, virus was still present in } \\
\text { the faecal sample 1-2 days after the respiratory } \\
\text { sample tested negative. }\end{array}$ \\
\hline
\end{tabular}




\begin{tabular}{|c|c|c|c|c|c|c|}
\hline 83 & $\begin{array}{l}\text { The Potential Spread of Infection } \\
\text { Caused by Aerosol Contamination } \\
\text { of Surfaces after Flushing a } \\
\text { Domestic Toilet }\end{array}$ & $\begin{array}{l}\text { Journal of Applied } \\
\text { Microbiology }\end{array}$ & June 2005 & $\mathrm{~F}$ & $\begin{array}{l}\text { Level 5: A study to determine the } \\
\text { level of aerosol formation and fall out } \\
\text { within a toilet cubicle after toilet } \\
\text { flushing through mimicking } \\
\text { infectious diarrhoea }\end{array}$ & $\begin{array}{l}\text { - Large numbers of microorganisms remained on the } \\
\text { toilet bowl surface and in the bowl water, which are } \\
\text { further dispersed to the air through further toilet } \\
\text { flushing. } \\
\text { - Indicates potential health risk to individuals who are } \\
\text { unaware of this mode of transmission within the } \\
\text { household. }\end{array}$ \\
\hline 84 & $\begin{array}{l}\text { Lifting the Lid on Toilet Plume } \\
\text { Aerosol: A Literature Review with } \\
\text { Suggestions for Future Research }\end{array}$ & $\begin{array}{l}\text { American Journal of } \\
\text { Infection Control }\end{array}$ & $\begin{array}{l}\text { October } \\
2012\end{array}$ & $\mathrm{~F}$ & $\begin{array}{l}\text { Level 5: A review on the potential } \\
\text { health risks of aerosol production } \\
\text { during toilet flushing }\end{array}$ & $\begin{array}{l}\text { - Toilet plume under toilet flushing may contribute to } \\
\text { infectious disease transmission. } \\
\text { - Further research to assess toilet plume risks, } \\
\text { especially in healthcare settings, is encouraged. }\end{array}$ \\
\hline 85 & $\begin{array}{l}\text { Respiratory Hygiene and Cough } \\
\text { Etiquette }\end{array}$ & $\begin{array}{l}\text { Infection Control in } \\
\text { the Dental Office }\end{array}$ & April 2020 & D & $\begin{array}{l}\text { Level 5: Expert opinion on } \\
\text { respiratory hygiene and cough } \\
\text { etiquette }\end{array}$ & $\begin{array}{l}\text { - Prevention is the best method for respiratory disease } \\
\text { management. } \\
\text { - Proper hand hygiene and awareness on cough and } \\
\text { sneeze etiquette is encouraged for successful } \\
\text { prevention. }\end{array}$ \\
\hline 86 & $\begin{array}{l}\text { Bacterial Transfer from Mouth to } \\
\text { Different Utensils and from } \\
\text { Utensils to Food }\end{array}$ & $\begin{array}{l}\text { Graduate School of } \\
\text { Clemson University }\end{array}$ & $\begin{array}{l}\text { August } \\
2009\end{array}$ & E, $\mathrm{H}$ & $\begin{array}{l}\text { Level 5: A study on the transfer of } \\
\text { bacteria from mouth to different } \\
\text { utensils }\end{array}$ & $\begin{array}{l}\text { - There is a significant bacterial transfer from mouth } \\
\text { to utensils and further to food. }\end{array}$ \\
\hline 87 & $\begin{array}{l}\text { Helicobacter Pylori: Epidemiology } \\
\text { and Routes of Transmission }\end{array}$ & $\begin{array}{l}\text { Epidemiologic } \\
\text { Reviews }\end{array}$ & July 2000 & E, H & $\begin{array}{l}\text { Level 5: A review on the } \\
\text { epidemiology and routes of } \\
\text { transmission of Helicobacter pylori }\end{array}$ & $\begin{array}{l}\text { - H. pylori infection is prevalent in Chinese } \\
\text { immigrants in Australia who share chopsticks for } \\
\text { communal dishes. } \\
\text { - A common mode of H. pylori transmission involves } \\
\text { an oral-to-oral route through saliva. }\end{array}$ \\
\hline 88 & $\begin{array}{l}\text { Potential for Aerosolization of } \\
\text { Clostridium Difficile after } \\
\text { Flushing Toilets: The Role of } \\
\text { Toilet Lids in Reducing } \\
\text { Environmental Contamination } \\
\text { Risk }\end{array}$ & $\begin{array}{l}\text { The Journal for } \\
\text { Hospital Infection }\end{array}$ & $\begin{array}{l}\text { December } \\
2011\end{array}$ & $\mathrm{~F}$ & $\begin{array}{l}\text { Level 5: A study on iIn-situ testing } \\
\text { using faecal suspensions to mimic } \\
\text { disease bacteria and measure } \\
\text { microorganism aerosolization as well } \\
\text { as extent of splashing when toilet } \\
\text { flushing }\end{array}$ & $\begin{array}{l}\text { - There is a potential health risk of microorganism } \\
\text { environmental contamination due to lidless toilets; } \\
\text { their use is thus discouraged thus their use is } \\
\text { discouraged. }\end{array}$ \\
\hline 89 & $\begin{array}{l}\text { Mobility Decline in Old Age: A } \\
\text { Time to Intervene }\end{array}$ & $\begin{array}{l}\text { Exercise and Sport } \\
\text { Sciences Reviews }\end{array}$ & $\begin{array}{l}\text { January } \\
2013\end{array}$ & D & $\begin{array}{l}\text { Level 5: Expert opinion on mobility } \\
\text { impairment in ageing populations }\end{array}$ & $\begin{array}{l}\text { - Mobility decline is prominent in the old aged. } \\
\text { - It is important for behavioural measures to be in } \\
\text { place for mobility function improvement. } \\
\text { - Further rigorous clinical trials are needed. } \\
\text { - The treatment and prevention of mobility } \\
\text { impairments through expert collaboration are } \\
\text { essential. }\end{array}$ \\
\hline 90 & $\begin{array}{l}\text { Age-related Change in Mobility: } \\
\text { Perspectives from Life Course } \\
\text { Epidemiology and Geroscience }\end{array}$ & $\begin{array}{l}\text { The Journals of } \\
\text { Gerontology. Series } \\
\text { A, Biological Sciences } \\
\text { and Medical Sciences }\end{array}$ & March 2016 & D & $\begin{array}{l}\text { Level 5: Expert opinion on mobility } \\
\text { impairment in ageing populations, } \\
\text { explored through the perspectives of } \\
\text { epidemiology and geroscience }\end{array}$ & $\begin{array}{l}\text { - Physical deterioration in older persons results in } \\
\text { mobility loss and impairment. } \\
\text { - It is important for behavioural measures to be in } \\
\text { place to reduce the disability burden in populations. }\end{array}$ \\
\hline
\end{tabular}




\begin{tabular}{|c|c|c|c|c|c|c|}
\hline 91 & $\begin{array}{l}\text { Plastic Waste Inputs from Land } \\
\text { into the Ocean }\end{array}$ & Science & $\begin{array}{l}\text { February } \\
2015\end{array}$ & $\mathrm{E}$ & $\begin{array}{l}\text { Level 5: A report on the estimation of } \\
\text { plastic waste mass in oceans by } \\
\text { linking relevant worldwide data }\end{array}$ & $\begin{array}{l}\text { - The amount of plastic waste generated across } 192 \\
\text { coastal countries is determined. } \\
\text { - The major determining factors of a country's } \\
\text { contribution to plastic waste would be population } \\
\text { size and waste management system quality. } \\
\text { - An estimation is made on the cumulative plastic } \\
\text { waste quantity if waste management infrastructure is } \\
\text { not improved. }\end{array}$ \\
\hline 92 & $\begin{array}{l}\text { Microplastic Contamination of } \\
\text { Wild and Captive Flathead Grey } \\
\text { Mullet (Mugil Cephalus) }\end{array}$ & $\begin{array}{l}\text { International Journal } \\
\text { of Environmental } \\
\text { Research and Public } \\
\text { Health }\end{array}$ & March 2018 & $\mathrm{E}$ & $\begin{array}{l}\text { Level 5: An investigation on } \\
\text { microplastic ingestion in flathead } \\
\text { grey mullets }\end{array}$ & $\begin{array}{l}\text { - There was evidence of microplastic ingestion in the } \\
\text { mullets. } \\
\text { - Individual, local and global actions to counteract the } \\
\text { issue of plastic waste disposal into seas are } \\
\text { encouraged. }\end{array}$ \\
\hline 93 & $\begin{array}{l}\text { CityU Experts: Aerosol Droplets } \\
\text { from Toilet Flushing can Rise Up } \\
\text { to One Metre; Covering Toilet Lid } \\
\text { may not Completely Eliminate } \\
\text { Disease Transmission; Toilet } \\
\text { Bowl must be Regularly Cleaned }\end{array}$ & $\begin{array}{l}\text { The City University of } \\
\text { Hong Kong }\end{array}$ & $\begin{array}{l}\text { February } \\
2020\end{array}$ & $\mathrm{~F}$ & $\begin{array}{l}\text { Level 5: A study on how toilet } \\
\text { flushing may produce aerosol } \\
\text { droplets that facilitate disease } \\
\text { transmission }\end{array}$ & $\begin{array}{l}\text { - A single toilet flush can contaminate the washroom } \\
\text { through the spread of pathogens in the air. } \\
\text { - The covering of toilet lid before flushing for } \\
\text { washroom and air contamination reduction is } \\
\text { recommended. } \\
\text { Toilet lid covering may not completely inhibit } \\
\text { pathogenic dissemination due to potential space } \\
\text { between the lid and the bowl. }\end{array}$ \\
\hline 94 & $\begin{array}{l}\text { The Coronavirus Pandemic and } \\
\text { Aerosols: Does COVID-19 } \\
\text { Transmit via Expiratory Particles? }\end{array}$ & $\begin{array}{l}\text { Aerosol Science and } \\
\text { Technology }\end{array}$ & April 2020 & $\mathrm{D}$ & $\begin{array}{l}\text { Level 5: Expert opinion on the } \\
\text { potential of COVID-19 transmission } \\
\text { through expiratory particles }\end{array}$ & $\begin{array}{l}\text { - Aerosol transmission may play a major role in the } \\
\text { high transmissibility of COVID-19. } \\
\text { - Ordinary speech has a potential of aerosolizing } \\
\text { respiratory particles. } \\
\text { - There are scientific unknowns relating to the mode } \\
\text { of transmission. } \\
\text { - It is important for experts to collaborate closely and } \\
\text { effectively inform the public of potential infectious } \\
\text { aerosol emission all the time, such as during } \\
\text { coughing and sneezing. }\end{array}$ \\
\hline
\end{tabular}




\begin{tabular}{|c|c|c|c|c|c|c|}
\hline 95 & 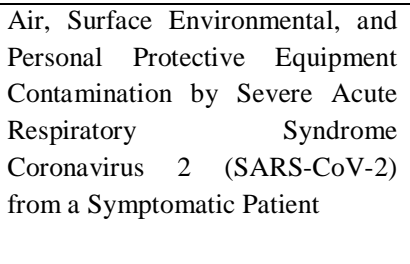 & $\begin{array}{l}\text { Journal of the } \\
\text { American Medical } \\
\text { Association }\end{array}$ & March 2020 & $\mathrm{D}$ & $\begin{array}{l}\text { Level 5: A study on the SARS-CoV-2 } \\
\text { contamination and persistence on } \\
\text { environmental surfaces and personal } \\
\text { protective equipment around COVID- } \\
19 \text { patients in isolation rooms }\end{array}$ & $\begin{array}{l}\text { - Environmental contamination is a highly potential } \\
\text { route of transmission for coronaviruses, which may } \\
\text { contribute to incidences of nosocomial transmission } \\
\text { of COVID-19 in hospitals. } \\
\text { - Further studies need to be conducted on the mode of } \\
\text { transmission of COVID-19 and the extent of } \\
\text { environmental contamination. }\end{array}$ \\
\hline 96 & $\begin{array}{l}\text { Protection and } \\
\text { Policies against } \\
(\text { COVID-19) }\end{array}$ & $\begin{array}{l}\text { Le Infezioni in } \\
\text { Medicina }\end{array}$ & 2020 & $\mathrm{G}$ & $\begin{array}{l}\text { Level 5: Expert opinion on COVID- } \\
19 \text { transmission, the stability of the } \\
\text { virus, and relevant measures of } \\
\text { prevention }\end{array}$ & $\begin{array}{l}\text { - The coronavirus can remain in airs and surfaces for } \\
\text { sustained periods of time. } \\
\text { - Recommendation of household disinfection is made. }\end{array}$ \\
\hline 97 & $\begin{array}{l}\text { Prevalence of Multidrug-resistant } \\
\text { Bacteria on Mobile Phone Surface }\end{array}$ & $\begin{array}{l}\text { Journal of Microscopy } \\
\text { and Ultrastructure }\end{array}$ & 2020 & $\mathrm{G}$ & $\begin{array}{l}\text { Level 5: A study on multi-drug } \\
\text { resistant bacteria on mobile phones }\end{array}$ & $\begin{array}{l}\text { - Nosocomial infection spread is accelerated by } \\
\text { microorganism presence on the mobile phones of } \\
\text { healthcare workers. } \\
\text { - Disinfection practices for phones in hospitals to ease } \\
\text { potential health risks is recommended. }\end{array}$ \\
\hline 98 & $\begin{array}{l}\text { Degree of Bacterial Contamination } \\
\text { of Mobile Phone and Computer } \\
\text { Keyboard Surfaces and Efficacy of } \\
\text { Disinfection with Chlorhexidine } \\
\text { Digluconate and Triclosan to its } \\
\text { Reduction }\end{array}$ & $\begin{array}{l}\text { International Journal } \\
\text { of Environmental } \\
\text { Research Public } \\
\text { Health }\end{array}$ & $\begin{array}{l}\text { October } \\
2018\end{array}$ & $\mathrm{G}$ & $\begin{array}{l}\text { Level 5: A study on the bacterial } \\
\text { contamination of mobile phone and } \\
\text { computer keyboard surfaces as well } \\
\text { as the subsequent disinfection } \\
\text { efficacy of selected disinfectants }\end{array}$ & $\begin{array}{l}\text { - A high degree of surface contamination is found on } \\
\text { both surfaces. } \\
\text { - Disinfection with simple antibacterial wet wipes to } \\
\text { significantly reduce microbial contamination is } \\
\text { recommended. }\end{array}$ \\
\hline 99 & $\begin{array}{l}\text { Association of Household Food- } \\
\text { and Drink-Sharing Practices with } \\
\text { Human Herpesvirus } 8 \\
\text { Seroconversion in a Cohort of } \\
\text { Zambian Children }\end{array}$ & $\begin{array}{l}\text { The Journal of } \\
\text { Infectious Diseases }\end{array}$ & $\begin{array}{l}\text { October } \\
2017\end{array}$ & $\mathrm{H}$ & $\begin{array}{l}\text { Level } 2 \mathrm{~b} \text { : An individual cohort study } \\
\text { on the link between household food } \\
\text { and drink sharing behaviour and the } \\
\text { risk of HHV-8 transmission }\end{array}$ & $\begin{array}{l}\text { - There is a temporal association between food and } \\
\text { drink sharing practices and HHV-8 transmission. } \\
\text { Such sharing practices should be minimised to reduce } \\
\text { transmission risks, in particular for households with } \\
\text { large sibling numbers. }\end{array}$ \\
\hline 100 & $\begin{array}{l}\text { The Clinical Toxicology of } \\
\text { Sodium Hypochlorite }\end{array}$ & $\begin{array}{l}\text { Clinical Toxicology } \\
\text { Philadelphia }\end{array}$ & $\begin{array}{l}\text { January } \\
2018\end{array}$ & $\mathrm{G}$ & $\begin{array}{l}\text { Level 5: A review on the clinical } \\
\text { toxicology of sodium hypochlorite }\end{array}$ & $\begin{array}{l}\text { - The unintended ingestion of household bleach in } \\
\text { large amounts may pose severe health risks such as } \\
\text { corrosive injury that may be fatal. }\end{array}$ \\
\hline 101 & $\begin{array}{l}\text { Occurrence of Household Mould } \\
\text { and Efficacy of Sodium } \\
\text { Hypochlorite Disinfectant }\end{array}$ & $\begin{array}{l}\text { Journal of } \\
\text { Occupational and } \\
\text { Environmental } \\
\text { Hygiene }\end{array}$ & 2012 & G & $\begin{array}{l}\text { Level 5: A study on the appearance of } \\
\text { household mould and the disinfecting } \\
\text { capability of sodium hypochlorite on } \\
\text { household surfaces }\end{array}$ & $\begin{array}{l}\text { - Low concentrations of sodium hypochlorite } \\
\text { significantly reduce mould and related allergens. }\end{array}$ \\
\hline 102 & $\begin{array}{l}\text { Efficacy of Sodium Hypochlorite } \\
\text { Disinfectant on the Viability and } \\
\text { Allergenic Properties of } \\
\text { Household Mould }\end{array}$ & $\begin{array}{l}\text { Journal of Allergy and } \\
\text { Clinical Immunology }\end{array}$ & $\begin{array}{l}\text { February } \\
2004\end{array}$ & $\mathrm{G}$ & $\begin{array}{l}\text { Level 5: A study on the efficacy of } \\
\text { sodium hypochlorite as a disinfectant } \\
\text { for household moulds }\end{array}$ & $\begin{array}{l}\text { - Low concentrations of sodium hypochlorite } \\
\text { significantly reduce mould and related allergens. }\end{array}$ \\
\hline
\end{tabular}




\begin{tabular}{|c|c|c|c|c|c|c|}
\hline 103 & $\begin{array}{l}\text { Transmission of Mutans } \\
\text { Streptococci in Mother-Child Pairs }\end{array}$ & $\begin{array}{l}\text { The Indian Journal of } \\
\text { Medical Research }\end{array}$ & $\begin{array}{l}\text { August } \\
2016\end{array}$ & $\mathrm{H}$ & $\begin{array}{l}\text { Level 4: A case series evaluating the } \\
\text { transmission of dental caries (Mutans } \\
\text { Streptococci) from mother to child }\end{array}$ & $\begin{array}{l}\text { - A vertical transmission of Mutans Streptococci from } \\
\text { mother to child is concluded. } \\
\text { - Further development of strategies to reduce food and } \\
\text { utensil sharing between mothers and children is } \\
\text { recommended. }\end{array}$ \\
\hline 104 & $\begin{array}{lrr}\text { Aerosol } & \text { Emission } & \text { and } \\
\text { Superemission during } & \text { Human } \\
\text { Speech Increase with } & \text { Voice } \\
\text { Loudness } & & \end{array}$ & Scientific Reports & $\begin{array}{l}\text { February } \\
2019\end{array}$ & I & $\begin{array}{l}\text { Level 5: A review on the potential of } \\
\text { aerosol emission and disease } \\
\text { transmission through human speech }\end{array}$ & $\begin{array}{l}\text { - Particle emission during speech has a positive } \\
\text { correlation with speech loudness. } \\
\text { - Respiratory infectious disease transmission is } \\
\text { facilitated by many unknown physiological factors } \\
\text { such as speech. }\end{array}$ \\
\hline 105 & $\begin{array}{l}\text { COVID-19 Transmission through } \\
\text { Asymptomatic Carriers is a } \\
\text { Challenge to Containment }\end{array}$ & $\begin{array}{l}\text { Influenza and Other } \\
\text { Respiratory Viruses }\end{array}$ & April 2020 & $\mathrm{I}, \mathrm{J}$ & $\begin{array}{l}\text { Level 5: A review on the transmission } \\
\text { of COVID-19 through asymptomatic } \\
\text { individuals and the associated } \\
\text { challenges }\end{array}$ & $\begin{array}{l}\text { - Asymptomatic transmission of COVID-19 is } \\
\text { possible between persons within communities. }\end{array}$ \\
\hline 106 & $\begin{array}{l}\text { Routes of Transmission of } \\
\text { Influenza A H1N1, SARS CoV, } \\
\text { and Norovirus in Air Cabin: } \\
\text { Comparative Analyses }\end{array}$ & $\begin{array}{l}\text { International Journal } \\
\text { of Indoor } \\
\text { Environment and } \\
\text { Health }\end{array}$ & $\begin{array}{l}\text { January } \\
2018\end{array}$ & $\mathrm{~J}$ & $\begin{array}{l}\text { Level 5: A model simulation to assess } \\
\text { the transmission routes of various } \\
\text { infectious viruses }\end{array}$ & $\begin{array}{l}\text { - Virus control in indoor environments such as } \\
\text { airplanes should take into consideration respiratory } \\
\text { and enteric transmission routes. } \\
\text { - A method to analyse the comparative significance of } \\
\text { different modes of virus transmission is highlighted. }\end{array}$ \\
\hline 107 & $\begin{array}{l}\text { Epidemiological Characteristics of } \\
\text { the First } 53 \text { Laboratory-confirmed } \\
\text { Cases of COVID-19 Epidemic in } \\
\text { Hong Kong, } 13 \text { February } 2020\end{array}$ & Eurosurveillance & April 2020 & $\mathrm{I}, \mathrm{J}$ & $\begin{array}{l}\text { Level 4: A case series on the key } \\
\text { epidemiological parameters of } \\
\text { COVID-19 cases in Hong Kong }\end{array}$ & $\begin{array}{l}\text { - The risk of transmission may be heightened through } \\
\text { increased social contact } \\
\text { - Physical distancing is a key measure to counteract } \\
\text { the pandemic }\end{array}$ \\
\hline 108 & $\begin{array}{lr}\text { Towards } & \text { Aerodynamically } \\
\text { Equivalent COVID19 } 1.5 \mathrm{~m} \text { Social } \\
\text { Distancing for Walking and } \\
\text { Running }\end{array}$ & Journal Pre-Print & $\begin{array}{l}\text { January } \\
2020\end{array}$ & I & $\begin{array}{l}\text { Level 5: A mathematical model to } \\
\text { understand the aerodynamics } \\
\text { associated with virus transmission } \\
\text { and the reasoning behind social } \\
\text { distancing }\end{array}$ & $\begin{array}{l}\text { - The } 1.5 \text {-meter social distancing suggestion may not } \\
\text { suffice if the aerodynamics associated with walking } \\
\text { and running is taken into consideration. } \\
\text { - Further work to understand the effect of } \\
\text { aerodynamic factors such as head-wind on droplet } \\
\text { transmissions is necessary. }\end{array}$ \\
\hline 109 & $\begin{array}{l}\text { COVID-19 Lockdowns } \text { Cause } \\
\text { Global Air Pollution Declines with } \\
\text { Implications for Public Health } \\
\text { Risk }\end{array}$ & Journal Pre-Print & April 2020 & I & $\begin{array}{l}\text { Level 5: A study on the declination of } \\
\text { global air pollution as a result of } \\
\text { reduced activity in COVID-19 }\end{array}$ & $\begin{array}{l}\text { - Health hazards such as premature deaths and } \\
\text { paediatric asthma associated with air pollution have } \\
\text { been minimised as a result of reduced activity in } \\
\text { COVID-19. } \\
\text { - There are potential health benefits from reduced air } \\
\text { pollutant emissions as a result of decreased } \\
\text { economic activity during the pandemic. }\end{array}$ \\
\hline 110 & $\begin{array}{l}\text { COVID-19 as a Factor Influencing } \\
\text { Air Pollution? }\end{array}$ & $\begin{array}{l}\text { Environmental } \\
\text { Pollution }\end{array}$ & April 2020 & I & $\begin{array}{l}\text { Level 5: A review on the impacts of } \\
\text { COVID-19 on air pollution }\end{array}$ & $\begin{array}{l}\text { - The emergence of COVID-19 has been followed by } \\
\text { decreased air pollution in areas like China, and } \\
\text { subsequently a reduced number of fatalities as a } \\
\text { result of air pollution. } \\
\text { - There are potential benefits of non-communicable } \\
\text { disease prevention due to air pollution reduction. }\end{array}$ \\
\hline
\end{tabular}




\begin{tabular}{|c|c|c|c|c|c|c|}
\hline 111 & $\begin{array}{l}\text { Air Pollution and Public Health: } \\
\text { Emerging Hazards and Improved } \\
\text { Understanding of Risk }\end{array}$ & $\begin{array}{l}\text { Environmental } \\
\text { Geochemistry and } \\
\text { Health }\end{array}$ & June 2015 & I & $\begin{array}{l}\text { Level 5: A study on air pollution as } \\
\text { an emerging public health hazard }\end{array}$ & $\begin{array}{l}\text { - Air pollution is historically linked to increased } \\
\text { respiratory and cardiovascular mortality. } \\
\text { - Air quality improvement is a significant challenge. } \\
\text { - There is a need for effective policies to ease the } \\
\text { burden of air pollution on health hazards. }\end{array}$ \\
\hline 112 & $\begin{array}{l}\text { Point of View: How Scientists can } \\
\text { Reduce Their Carbon Footprint }\end{array}$ & eLife & March 2016 & $\bar{J}$ & $\begin{array}{l}\text { Level 5: Expert opinion on the impact } \\
\text { of reduced long-distance air travel on } \\
\text { carbon footprint and the reduction of } \\
\text { greenhouse gas emissions }\end{array}$ & $\begin{array}{l}\text { - Carbon dioxide emissions are significantly reduced } \\
\text { under decreased long-distance travel amongst the } \\
\text { scientific community. }\end{array}$ \\
\hline 113 & $\begin{array}{l}\text { What is the Evidence for Mass } \\
\text { Gatherings During Global } \\
\text { Pandemics? }\end{array}$ & $\begin{array}{l}\text { Centre for Evidence- } \\
\text { Based Medicine }\end{array}$ & March 2020 & I & $\begin{array}{l}\text { Level 5: A review on the potential } \\
\text { effects of mass gatherings on } \\
\text { infectious diseases }\end{array}$ & $\begin{array}{l}\text { - Measures involving the restriction and cancellation } \\
\text { of mass gatherings appear important, but relevant } \\
\text { evidence is lacking. } \\
\text { - Active analysis of risks associated to mass } \\
\text { gatherings is encouraged on a case-by-case basis. }\end{array}$ \\
\hline 114 & 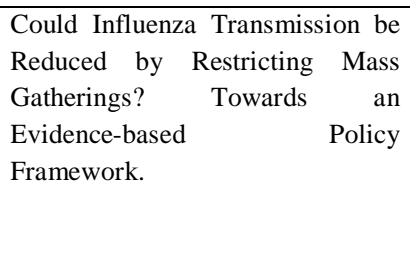 & $\begin{array}{l}\text { Journal of } \\
\text { Epidemiology and } \\
\text { Global Health }\end{array}$ & $\begin{array}{l}\text { August } \\
2011\end{array}$ & I & $\begin{array}{l}\text { Level 5: A narrative analysis on the } \\
\text { effect of mass gathering restrictions } \\
\text { on influenza transmission risks }\end{array}$ & $\begin{array}{l}\text { - While mass gathering restrictions together with other } \\
\text { social distancing measures may help reduce } \\
\text { transmission, the individual effects of mass gathering } \\
\text { restriction remain inconclusive. } \\
\text { - The duration of the event and crowd density may } \\
\text { significantly influence influenza transmission risks. } \\
\text { - }\end{array}$ \\
\hline 115 & $\begin{array}{l}\text { Mass Gatherings Medicine: Public } \\
\text { Health Issues Arising from Mass } \\
\text { Gathering Religious and Sporting } \\
\text { Events }\end{array}$ & The Lancet & May 2019 & $\mathrm{I}$ & $\begin{array}{l}\text { Level 5: A review on the association } \\
\text { of mass gathering events with } \\
\text { potential public health hazards }\end{array}$ & $\begin{array}{l}\text { - Extensive crowd interactions raise burdens on health } \\
\text { systems, especially for large-scale sporting or } \\
\text { religious events. } \\
\text { Further research into public health prevention and } \\
\text { surveillance is recommended. }\end{array}$ \\
\hline 116 & $\begin{array}{l}\text { Influenza Outbreaks During World } \\
\text { Youth Day } 2008 \text { Mass Gathering }\end{array}$ & $\begin{array}{l}\text { Emerging Infectious } \\
\text { Diseases }\end{array}$ & May 2010 & I & $\begin{array}{l}\text { Level 5: A review on influenza } \\
\text { outbreaks during the } 2008 \text { World } \\
\text { Youth Day mass gathering }\end{array}$ & $\begin{array}{l}\text { - Mass gatherings introduce and amplify viruses. } \\
\text { - Isolated viruses may impose unpredictable risks on } \\
\text { communities. } \\
\text { - Authorities and hospitals are responsible for } \\
\text { managing influenza outbreaks with greater } \\
\text { flexibility. }\end{array}$ \\
\hline 117 & $\begin{array}{l}\text { Measles Virus Spread Initiated at } \\
\text { International Mass Gatherings in } \\
\text { Europe, } 2011\end{array}$ & Eurosurveillance & $\begin{array}{l}\text { September } \\
2014\end{array}$ & I & $\begin{array}{l}\text { Level 5: Expert analysis on the } \\
\text { associated measles virus spread } \\
\text { during the } 2011 \text { mass gatherings }\end{array}$ & $\begin{array}{l}\text { - Transmission chains of the measles virus originated } \\
\text { from mass sporting events. } \\
\text { - Importance of measles virus transmission chain } \\
\text { monitoring and surveillance is reinforced. }\end{array}$ \\
\hline
\end{tabular}

KEY 1 - MEASURES
A $\mid$ Engage in Regular Handwashing
F $\mid$ Close Toilet Cover When Flushing 


\begin{tabular}{l|ll|l} 
B & Wear Face Mask & G & Disinfect Household Surfaces \\
C & Avoid Touching the Face & H & Avoid Sharing Utensils \\
D & Cover Mouth and Nose when Coughing and Sneezing & I & Avoid Crowds and Mass Gatherings \\
E & Bring Personal Utensils When Dining Out & J & Avoid Travel
\end{tabular}

\section{KEY 2 - OCEBM LEVEL OF EVIDENCE}

\begin{tabular}{l|l} 
LEVEL & \multicolumn{1}{|c}{ Therapy / Prevention, Aetiology / Harm } \\
1A & Systematic Review (SR) (with homogeneity) of Randomised Controlled Trials (RCTs) \\
1B & Individual RCT (with narrow Confidence Interval) \\
1C & All or none \\
2A & SR (with homogeneity) of cohort studies \\
2B & Individual cohort study (including low quality RCT; e.g., <80\% follow-up) \\
2C & "Outcomes" Research; Ecological studies \\
3A & SR (with homogeneity) of case-control studies \\
3B & Individual Case-Control Study \\
4 & Case-series (and poor quality cohort and case-control studies) \\
5 & Expert opinion without explicit critical appraisal, or based on physiology, bench research or "first principles" \\
Others & E.g. model simulations, non-human based experiment, in vitro or in situ studies, and statistical reports or dashboards
\end{tabular}


medRxiv preprint doi: https://doi.org/10.1101/2020.05.29.20116475; this version posted May 29, 2020. The copyright holder for this preprint

(which was not certified by peer review) is the author/funder, who has granted medRxiv a license to display the preprint in perpetuity.

It is made available under a CC-BY-NC-ND 4.0 International license .

\section{References}

1. Singer DRJ. Health policy and technology challenges in responding to the COVID-19 pandemic. Heal Policy Technol. Published online 2020.

2. World Health Organisation. Emergency Risk Management for Health - Overview. Emerg Risk Manag Heal Fact Sheets. 2013;(May Issue):1-6.

3. WHO. Health Emergency and Disaster Risk Management: Overview.; 2019. https://www.who.int/hac/techguidance/preparedness/health-emergency-and-disaster-riskmanagement-framework-eng.pdf?ua $=1$

4. WHO. Modes of transmission of virus causing COVID-19 $\square$ : implications for IPC precaution recommendations. Sci Br. 2020;(March):1-3. doi:10.1056/NEJMoa2001316.5.

5. Chan EYY, Shaw R. Public Health and Disasters: Health Emergency and Disaster Risk Management in Asia.; 2020.

6. Boslaugh S. Encyclopedia of Epidemiology.; 2012. doi:10.4135/9781412953948

7. Zhang J, Wu S, Xu L. Asymptomatic carriers of COVID-19 as a concern for disease prevention and control: more testing, more follow-up. Biosci Trends. Published online 2020. doi:10.5582/bst.2020.03069

8. Cascella M, Rajnik M, Cuomo A, Dulebohn SC, Di Napoli R. Features, Evaluation and Treatment Coronavirus (COVID-19).; 2020.

9. WHO. Health promotion and disease prevention through population-based measures, including action to address social determinants and health inequity. PLoS Negl Trop Dis. Published online 2013.

10. Chan EYY. Public Health Humanitarian Responses to Natural Disasters.; 2017. doi:10.4324/9781315667218

11. Wisner B, Adams J. 15 . Health promotion and community participation. Environ Heal Emergencies Disasters a Pract Guid. Published online 2003.

12. Laaser U, Dorey S, Nurse J. A plea for global health action bottom-up. Front Public Heal. Published online 2016. doi:10.3389/FPUBH.2016.00241

13. Oxford Centre for Evidence-based Medicine - Levels of Evidence. The Centre for Evidence-Based Medicine. Published 2009. https://www.cebm.net/2009/06/oxford-centreevidence-based-medicine-levels-evidence-march-2009/

14. Huang H, Fan C, Li M, et al. COVID-19: A Call for Physical Scientists and Engineers. ACS Nano. Published online 2020. doi:10.1021/acsnano.0c02618

15. van Doremalen N, Bushmaker T, Morris DH, et al. Aerosol and Surface Stability of SARS-CoV-2 as Compared with SARS-CoV-1. N Engl J Med. Published online 2020. doi:10.1056/NEJMc2004973

16. Liu J, Liao X, Qian S, et al. Community Transmission of Severe Acute Respiratory Syndrome Coronavirus 2, Shenzhen, China, 2020. Emerg Infect Dis. Published online 2020. doi:10.3201/eid2606.200239

17. Chan JFW, Yuan S, Kok KH, et al. A familial cluster of pneumonia associated with the 2019 novel coronavirus indicating person-to-person transmission: a study of a family cluster. Lancet. Published online 2020. doi:10.1016/S0140-6736(20)30154-9

18. Hui KPY, Chan LLY, Kuok DIT, et al. Tropism and innate host responses of influenza A/H5N6 virus: An analysis of ex vivo and in vitro cultures of the human respiratory tract. Eur Respir J. Published online 2017. doi:10.1183/13993003.01710-2016

19. Lu C wei, Liu X fen, Jia Z fang. 2019-nCoV transmission through the ocular surface must 
medRxiv preprint doi: https://doi.org/10.1101/2020.05.29.20116475; this version posted May 29, 2020. The copyright holder for this preprint

(which was not certified by peer review) is the author/funder, who has granted medRxiv a license to display the preprint in perpetuity.

It is made available under a CC-BY-NC-ND 4.0 International license .

not be ignored. Lancet. Published online 2020. doi:10.1016/S0140-6736(20)30313-5

20. Bai Y, Yao L, Wei T, et al. Presumed Asymptomatic Carrier Transmission of COVID-19. JAMA - J Am Med Assoc. Published online 2020. doi:10.1001/jama.2020.2565

21. World Health Organization. What can I do? Emergencies preparedness, response. Published 2010. Accessed May 17, 2020.

https://www.who.int/csr/disease/swineflu/frequently_asked_questions/what/en/

22. Sungnak W, Huang N, Bécavin C, et al. SARS-CoV-2 entry factors are highly expressed in nasal epithelial cells together with innate immune genes. Nat Med. Published online 2020. doi:10.1038/s41591-020-0868-6

23. Lange JH. Use of disposable face masks for public health protection against SARS. $J$ Epidemiol Community Health. Published online 2004.

24. Lau JTF, Tsui H, Lau M, Yang X. SARS Transmission, Risk Factors, and Prevention in Hong Kong. Emerg Infect Dis. Published online 2004. doi:10.3201/eid1004.030628

25. Lo JYC, Tsang THF, Leung YH, Yeung EYH, Wu T, Lim WWL. Respiratory infections during SARS Outbreak, Hong Kong, 2003. Emerg Infect Dis. Published online 2005. doi:10.3201/eid1111.050729

26. Macias AE, de la Torre A, Moreno-Espinosa S, Leal PE, Bourlon MT, Ruiz-Palacios GM. Controlling the novel A (H1N1) influenza virus: don't touch your face! J Hosp Infect. Published online 2009. doi:10.1016/j.jhin.2009.06.017

27. Desai AN, Patel P. Stopping the Spread of COVID-19. JAMA - J Am Med Assoc. Published online 2020. doi:10.1001/jama.2020.4269

28. Centre for Health Protection. Prevention of Coronavirus Disease 2019 (COVID-19). Health Information - Communicable Diseases. Published 2020. https://www.chp.gov.hk/files/pdf/prevention_of_covid_19_en.pdf

29. CDC. Fact Sheet for SARS Patients and Their Close Contact. Published online 2004. https://www.cdc.gov/sars/about/fs-closecontact.pdf

30. Organisation World Health. WHO Guidelines On Hand Hygiene in Health Care. World Heal Organ. 2009;30(1):270. doi:10.1086/600379

31. Tschudin-Sutter S, Sepulcri D, Dangel M, Ulrich A, Frei R, Widmer AF. Simplifying the World Health Organization Protocol: 3 Steps Versus 6 Steps for Performance of Hand Hygiene in a Cluster-randomized Trial. Clin Infect Dis. Published online 2019. doi:10.1093/cid/ciy948

32. Wong JSW, Lee JKF. The Common Missed Handwashing Instances and Areas after 15 Years of Hand-Hygiene Education. J Environ Public Health. Published online 2019. doi:10.1155/2019/5928924

33. Freeman MC, Stocks ME, Cumming O, et al. Systematic review: Hygiene and health: Systematic review of handwashing practices worldwide and update of health effects. Trop Med Int Heal. Published online 2014. doi:10.1111/tmi.12339

34. Arias A V., Garcell HG, Ochoa YR, Arias KF, Miranda FR. Assessment of hand hygiene techniques using the World Health Organization's six steps. J Infect Public Health. Published online 2016. doi:10.1016/j.jiph.2015.11.006

35. Ataee RA, Ataee MH, Mehrabi Tavana A, Salesi M. Bacteriological aspects of hand washing: A key for health promotion and infections control. Int J Prev Med. Published online 2017. doi:10.4103/2008-7802.201923

36. World Health Organization W. Coronavirus disease (COVID-19) advice for the public. Coronavirus disease (COVID-19) advice for the public. Published 2020. 
medRxiv preprint doi: https://doi.org/10.1101/2020.05.29.20116475; this version posted May 29, 2020. The copyright holder for this preprint

(which was not certified by peer review) is the author/funder, who has granted medRxiv a license to display the preprint in perpetuity.

It is made available under a CC-BY-NC-ND 4.0 International license .

https://www.who.int/emergencies/diseases/novel-coronavirus-2019/advice-for-public

37. CDC. How to Protect Yourself and Others. CDC.gov. Published online 2020.

38. Lotfinejad N, Peters A, Pittet D. Hand hygiene and the novel coronavirus pandemic: The role of healthcare workers. J Hosp Infect. Published online 2020.

doi:10.1016/j.jhin.2020.03.017

39. Tang JW, Liebner TJ, Craven BA, Settles GS. A schlieren optical study of the human cough with and without wearing masks for aerosol infection control. $J$ R Soc Interface. Published online 2009. doi:10.1098/rsif.2009.0295.focus

40. Leung NHL, Chu DKW, Shiu EYC, et al. Respiratory virus shedding in exhaled breath and efficacy of face masks. Nat Med. Published online 2020. doi:10.1038/s41591-0200843-2

41. Li Q, Guan X, Wu P, et al. Early transmission dynamics in Wuhan, China, of novel coronavirus-infected pneumonia. N Engl J Med. Published online 2020. doi:10.1056/NEJMoa2001316

42. Chughtai AA, Stelzer-Braid S, Rawlinson W, et al. Contamination by respiratory viruses on outer surface of medical masks used by hospital healthcare workers. BMC Infect Dis. Published online 2019. doi:10.1186/s12879-019-4109-x

43. Chin AWH, Chu JTS, Perera MRA, et al. Stability of SARS-CoV-2 in different environmental conditions. The Lancet Microbe. Published online 2020. doi:10.1016/s2666-5247(20)30003-3

44. Drexler M, (US) I of M. How Infection Works. In: What You Need to Know About Infectious Disease. ; 2010. doi:10.17226/13006

45. Kwok YLA, Gralton J, McLaws ML. Face touching: A frequent habit that has implications for hand hygiene. Am J Infect Control. Published online 2015. doi:10.1016/j.ajic.2014.10.015

46. Mueller SM, Martin S, Grunwald M. Self-touch: Contact durations and point of touch of spontaneous facial self-touches differ depending on cognitive and emotional load. PLoS One. Published online 2019. doi:10.1371/journal.pone.0213677

47. Liu M, Ou J, Zhang L, et al. Protective effect of hand-washing and good hygienic habits against seasonal influenza: A case-control study. Med (United States). Published online 2016. doi:10.1097/MD.0000000000003046

48. Wong VWY, Cowling BJ, Aiello AE. Hand hygiene and risk of influenza virus infections in the community: A systematic review and meta-analysis. Epidemiol Infect. Published online 2014. doi:10.1017/S095026881400003X

49. Curtis V, Cairncross S. Effect of washing hands with soap on diarrhoea risk in the community: A systematic review. Lancet Infect Dis. Published online 2003. doi:10.1016/S1473-3099(03)00606-6

50. Ejemot-Nwadiaro RI, Ehiri JE, Arikpo D, Meremikwu MM, Critchley JA. Hand washing promotion for preventing diarrhoea. Cochrane Database Syst Rev. Published online 2015. doi:10.1002/14651858.CD004265.pub3

51. Stevens S. Reducing the risk of infection: Hand washing technique. Community Eye Heal $J$. Published online 2008.

52. Bloomfield SF, Aiello AE, Cookson B, O'Boyle C, Larson EL. The effectiveness of hand hygiene procedures in reducing the risks of infections in home and community settings including handwashing and alcohol-based hand sanitizers. Am J Infect Control. Published online 2007. doi:10.1016/j.ajic.2007.07.001 
medRxiv preprint doi: https://doi.org/10.1101/2020.05.29.20116475; this version posted May 29, 2020. The copyright holder for this preprint

(which was not certified by peer review) is the author/funder, who has granted medRxiv a license to display the preprint in perpetuity. It is made available under a CC-BY-NC-ND 4.0 International license .

53. Pacitto A, Amato F, Salmatonidis A, et al. Effectiveness of commercial face masks to reduce personal PM exposure. Sci Total Environ. Published online 2019.

doi:10.1016/j.scitotenv.2018.09.109

54. Hansstein FV, Echegaray F. Exploring motivations behind pollution-mask use in a sample of young adults in urban China. Global Health. Published online 2018.

doi:10.1186/s12992-018-0441-y

55. World Health Organization. WHO | Air pollution. World Health Organization.

56. Zhang W, Qian CN, Zeng YX. Air pollution: A smoking gun for cancer. Chin J Cancer. Published online 2014. doi:10.5732/cjc.014.10034

57. Rumana HS, Sharma RC, Beniwal V, Sharma AK. A retrospective approach to assess human health risks associated with growing air pollution in urbanized area of Thar Desert, western Rajasthan, India. J Environ Heal Sci Eng. Published online 2014. doi:10.1186/2052-336X-12-23

58. Corstjens PLAM, Abrams WR, Malamud D. Saliva and viral infections. Periodontol 2000. Published online 2016. doi:10.1111/prd.12112

59. Vishwanath R, Selvabai AP, Shanmugam P. Detection of bacterial pathogens in the hands of rural school children across different age groups and emphasizing the importance of hand wash. J Prev Med Hyg. Published online 2019. doi:10.15167/24214248/jpmh2019.60.2.1186

60. Siddharta A, Pfaender S, Vielle NJ, et al. Virucidal activity of world health organizationrecommended formulations against enveloped viruses, including zika, ebola, and emerging coronaviruses. J Infect Dis. Published online 2017. doi:10.1093/infdis/jix046

61. Luby SP, Agboatwalla M, Feikin DR, et al. Effect of handwashing on child health: A randomised controlled trial. Lancet. Published online 2005. doi:10.1016/S01406736(05)66912-7

62. Paludan-Müller AS, Boesen K, Klerings I, Jørgensen KJ, Munkholm K. Hand cleaning with ash for reducing the spread of viral and bacterial infections: a rapid review. Cochrane Database Syst Rev. Published online 2020. doi:10.1002/14651858.CD013597

63. Ogunsola FT, Adesiji YO. Comparison of four methods of hand washing in situations of inadequate water supply. West Afr J Med. Published online 2008.

64. Davies A, Thompson KA, Giri K, Kafatos G, Walker J, Bennett A. Testing the efficacy of homemade masks: would they protect in an influenza pandemic? Disaster Med Public Health Prep. Published online 2013. doi:10.1017/dmp.2013.43

65. Konda A, Prakash A, Moss GA, Schmoldt M, Grant GD, Guha S. Aerosol Filtration Efficiency of Common Fabrics Used in Respiratory Cloth Masks. ACS Nano. Published online 2020. doi:10.1021/acsnano.0c03252

66. Hadaway A. Handwashing: Clean Hands Save Lives. J Consum Health Internet. Published online 2020. doi:10.1080/15398285.2019.1710981

67. Fung ICH, Cairncross S. Effectiveness of handwashing in preventing SARS: A review. Trop Med Int Heal. Published online 2006. doi:10.1111/j.1365-3156.2006.01734.x

68. Jensen D. Efficacy of Handwashing Duration and Drying Methods. In: 2012 Annual Meeting. ; 2012.

69. Wu J, Xu F, Zhou W, et al. Risk Factors for SARS among Persons without Known Contact with SARS Patients, Beijing, China. Emerg Infect Dis. Published online 2004. doi:10.3201/eid1002.030730

70. Bae S, Kim M-C, Kim JY, et al. Effectiveness of Surgical and Cotton Masks in Blocking 
medRxiv preprint doi: https://doi.org/10.1101/2020.05.29.20116475; this version posted May 29, 2020. The copyright holder for this preprint

(which was not certified by peer review) is the author/funder, who has granted medRxiv a license to display the preprint in perpetuity.

It is made available under a CC-BY-NC-ND 4.0 International license .

SARS-CoV-2: A Controlled Comparison in 4 Patients. Ann Intern Med. Published online 2020. doi:10.7326/m20-1342

71. Leung CC, Lam TH, Cheng KK. Mass masking in the COVID-19 epidemic: people need guidance. Lancet. Published online 2020. doi:10.1016/S0140-6736(20)30520-1

72. Cheng VCC, Wong S-C, Chuang VWM, et al. The role of community-wide wearing of face mask for control of coronavirus disease 2019 (COVID-19) epidemic due to SARSCoV-2. J Infect. Published online 2020. doi:10.1016/j.jinf.2020.04.024

73. World Health Organization W. WHO Coronavirus Disease (COVID-19) Dashboard. WHO Coronavirus Disease (COVID-19) Dashboard. Published 2020. https://covid19. who.int/explorer

74. Eikenberry SE, Mancuso M, Iboi E, et al. To mask or not to mask: Modeling the potential for face mask use by the general public to curtail the COVID-19 pandemic. Infect Dis Model. Published online 2020. doi:10.1016/j.idm.2020.04.001

75. Kampf G, Todt D, Pfaender S, Steinmann E. Persistence of coronaviruses on inanimate surfaces and their inactivation with biocidal agents. J Hosp Infect. Published online 2020. doi:10.1016/j.jhin.2020.01.022

76. Bourouiba L. Turbulent Gas Clouds and Respiratory Pathogen Emissions: Potential Implications for Reducing Transmission of COVID-19. JAMA - J Am Med Assoc. Published online 2020. doi:10.1001/jama.2020.4756

77. Khurshid Z, Asiri FYI, Al Wadaani H. Human saliva: Non-invasive fluid for detecting novel coronavirus (2019-nCoV). Int J Environ Res Public Health. Published online 2020. doi:10.3390/ijerph17072225

78. To KKW, Tsang OTY, Chik-Yan Yip C, et al. Consistent detection of 2019 novel coronavirus in saliva. Clin Infect Dis. Published online 2020. doi:10.1093/cid/ciaa149

79. Coelho AÍM, Milagres RCRM, Martins J de FL, de Azeredo RMC, Santana ÂMC. Microbiological contamination of environments and surfaces at commercial restaurants. Cienc e Saude Coletiva. Published online 2010. doi:10.1590/S1413-81232010000700071

80. Mendes RA, Coelho AÍM, de Azeredo RMC. Contamination by Bacillus cereus on equipment and utensil surfaces in a food and nutrition service unit. Cienc e Saude Coletiva. Published online 2011. doi:10.1590/S1413-81232011001000030

81. Zhang T, Cui X, Zhao X, et al. Detectable SARS-CoV-2 viral RNA in feces of three children during recovery period of COVID-19 pneumonia. J Med Virol. Published online 2020. doi:10.1002/jmv.25795

82. Chinese University of Hong Kong. CUHK Finds that the Coronavirus Can Persist in Stool after Its Clearance in Respiratory Tract Will Conduct Stool Test for People in Quarantine Camps for Early Identification. 2020. Accessed May 17, 2020.

https://www.med.cuhk.edu.hk/press-releases/cuhk-finds-that-the-coronavirus-can-persistin-stool-after-its-clearance-in-respiratory-tract-will-conduct-stool-test-for-people-inquarantine-camps-for-early-identification

83. Barker J, Jones M V. The potential spread of infection caused by aerosol contamination of surfaces after flushing a domestic toilet. J Appl Microbiol. Published online 2005. doi:10.1111/j.1365-2672.2005.02610.x

84. Johnson DL, Mead KR, Lynch RA, Hirst DVL. Lifting the lid on toilet plume aerosol: A literature review with suggestions for future research. Am J Infect Control. Published online 2013. doi:10.1016/j.ajic.2012.04.330

85. Chavis S, Ganesh N. Respiratory Hygiene and Cough Etiquette. In: Infection Control in 
medRxiv preprint doi: https://doi.org/10.1101/2020.05.29.20116475; this version posted May 29, 2020. The copyright holder for this preprint

(which was not certified by peer review) is the author/funder, who has granted medRxiv a license to display the preprint in perpetuity.

It is made available under a CC-BY-NC-ND 4.0 International license .

the Dental Office. ; 2020. doi:10.1007/978-3-030-30085-2_7

86. Purohit C. Bacterial transfer from mouth to different utensils and from utensils to food. Environ Heal East Africa. Published online 2009:1-46.

87. Brown LM. Helicobacter pylori: Epidemiology and routes of transmission. Epidemiol Rev. 2000;22(2):283-297. doi:10.1093/oxfordjournals.epirev.a018040

88. Best EL, Sandoe JAT, Wilcox MH. Potential for aerosolization of Clostridium difficile after flushing toilets: The role of toilet lids in reducing environmental contamination risk. J Hosp Infect. Published online 2012. doi:10.1016/j.jhin.2011.08.010

89. Manini TM. Mobility decline in old age: A time to intervene. Exerc Sport Sci Rev. Published online 2013. doi:10.1097/JES.0b013e318279fdc5

90. Ferrucci L, Cooper R, Shardell M, Simonsick EM, Schrack JA, Kuh D. Age-related change in mobility: Perspectives from life course epidemiology and geroscience. Journals Gerontol - Ser A Biol Sci Med Sci. Published online 2016. doi:10.1093/gerona/glw043

91. Jambeck JR, Geyer R, Wilcox C, et al. Plastic waste inputs from land into the ocean. Science (80- ). Published online 2015. doi:10.1126/science.1260352

92. Cheung LTO, Lui CY, Fok L. Microplastic contamination ofwild and captive flathead grey mullet (Mugil cephalus). Int J Environ Res Public Health. Published online 2018. doi:10.3390/ijerph15040597

93. City University of Hong Kong. CityU experts: Aerosol droplets from toilet flushing can rise up to one metre Covering toilet lid may not completely eliminate disease transmission Toilet bowl must be regularly cleaned. Published 2020. Accessed May 17, 2020. https://www.cityu.edu.hk/media/press-release/2020/02/13/cityu-experts-aerosol-dropletstoilet-flushing-can-rise-one-metre-covering-toilet-lid-may-not-completely-eliminatedisease-transmission-toilet-bowl-must-be-regularly-cleaned

94. Asadi S, Bouvier N, Wexler AS, Ristenpart WD. The coronavirus pandemic and aerosols: Does COVID-19 transmit via expiratory particles? Aerosol Sci Technol. Published online 2020. doi:10.1080/02786826.2020.1749229

95. Ong SWX, Tan YK, Chia PY, et al. Air, Surface Environmental, and Personal Protective Equipment Contamination by Severe Acute Respiratory Syndrome Coronavirus 2 (SARSCoV-2) from a Symptomatic Patient. JAMA - J Am Med Assoc. Published online 2020. doi:10.1001/jama.2020.3227

96. Fathizadeh H, Maroufi P, Momen-Heravi M, et al. Protection and disinfection policies against SARS-CoV-2 (COVID-19). Le Infez Med. Published online 2020.

97. Rozario S, Rahman H, Fakhruddin AM, Rabbani K. Prevalence of multidrug-Resistant bacteria on mobile phone surface. J Microsc Ultrastruct. Published online 2020. doi:10.4103/jmau.jmau_7_19

98. Koscova J, Hurnikova Z, Pistl J. Degree of bacterial contamination of mobile phone and computer keyboard surfaces and efficacy of disinfection with chlorhexidine digluconate and triclosan to its reduction. Int J Environ Res Public Health. Published online 2018. doi:10.3390/ijerph15102238

99. Crabtree KL, Wojcicki JM, Minhas V, Kankasa C, Mitchell C, Wood C. Association of Household Food- and Drink-Sharing Practices with Human Herpesvirus 8 Seroconversion in a Cohort of Zambian Children. J Infect Dis. Published online 2017. doi:10.1093/infdis/jix399

100. Slaughter RJ, Watts M, Vale JA, Grieve JR, Schep LJ. The clinical toxicology of sodium hypochlorite. Clin Toxicol. Published online 2019. doi:10.1080/15563650.2018.1543889 
medRxiv preprint doi: https://doi.org/10.1101/2020.05.29.20116475; this version posted May 29, 2020. The copyright holder for this preprint

(which was not certified by peer review) is the author/funder, who has granted medRxiv a license to display the preprint in perpetuity.

It is made available under a CC-BY-NC-ND 4.0 International license .

101. Reynolds KA, Boone S, Bright KR, Gerba CP. Occurrence of household mold and efficacy of sodium hypochlorite disinfectant. J Occup Environ Hyg. Published online 2012. doi:10.1080/15459624.2012.724650

102. REYNOLDS K. Efficacy of sodium hypochlorite disinfectant on the viability and allergenic properties of household mold*1. J Allergy Clin Immunol. Published online 2004. doi:10.1016/j.jaci.2004.01.082

103. Damle SG, Yadav R, Garg S, et al. Transmission of mutans streptococci in mother-child pairs. Indian J Med Res. Published online 2016. doi:10.4103/0971-5916.195042

104. Asadi S, Wexler AS, Cappa CD, Barreda S, Bouvier NM, Ristenpart WD. Aerosol emission and superemission during human speech increase with voice loudness. Sci Rep. Published online 2019. doi:10.1038/s41598-019-38808-z

105. Yu X, Yang R. COVID-19 transmission through asymptomatic carriers is a challenge to containment. Influenza Other Respi Viruses. Published online 2020. doi:10.1111/irv.12743

106. Lei H, Li Y, Xiao S, et al. Routes of transmission of influenza A H1N1, SARS CoV, and norovirus in air cabin: Comparative analyses. Indoor Air. Published online 2018. doi:10.1111/ina.12445

107. Kwok KO, Wong VWY, Wei WI, Wong SYS, Tang JW-T. Epidemiological characteristics of the first 53 laboratory-confirmed cases of COVID-19 epidemic in Hong Kong, 13 February 2020. Eurosurveillance. Published online 2020. doi:10.2807/15607917.es.2020.25.16.2000155

108. Blocken B, Malizia F, van Druenen T, Marchal T. Towards Aerodynamically Equivalent COVID19 1.5 m Social Distancing for Walking and Running.; 2020.

109. Venter ZS, Aunan K, Chowdhury S, Lelieveld J. COVID-19 lockdowns cause global air pollution declines with implications for public health risk. medRxiv. Published online 2020. doi:10.1101/2020.04.10.20060673

110. Dutheil F, Baker JS, Navel V. COVID-19 as a factor influencing air pollution? Environ Pollut. Published online 2020. doi:10.1016/j.envpol.2020.114466

111. Kelly FJ, Fussell JC. Air pollution and public health: emerging hazards and improved understanding of risk. Environ Geochem Health. Published online 2015. doi:10.1007/s10653-015-9720-1

112. Nathans J, Sterling P. How scientists can reduce their carbon footprint. Elife. Published online 2016. doi:10.7554/eLife. 15928

113. Nuana D, Brassey J. What is the evidence for mass gatherings during global pandemics? Oxford Covid-19 Evidence Service.

114. Ishola DA, Phin N. Could influenza transmission be reduced by restricting mass gatherings? Towards an evidence-based policy framework. J Epidemiol Glob Health. Published online 2011. doi:10.1016/j.jegh.2011.06.004

115. Memish ZA, Steffen R, White P, et al. Mass gatherings medicine: public health issues arising from mass gathering religious and sporting events. Lancet. Published online 2019. doi:10.1016/S0140-6736(19)30501-X

116. Blyth CC, Foo H, van Hal SJ, et al. Influenza outbreaks during world youth day 2008 mass gathering. Emerg Infect Dis. Published online 2010. doi:10.3201/eid1605.091136

117. Santibanez S, Prosenc K, Lohr D, Pfaff G, Markocic OJ, Mankertz A. Measles virus spread initiated at international mass gatherings in Europe, 2011. Eurosurveillance. Published online 2014. doi:10.2807/1560-7917.es2014.19.35.20891 
medRxiv preprint doi: https://doi.org/10.1101/2020.05.29.20116475; this version posted May 29, 2020. The copyright holder for this preprint

(which was not certified by peer review) is the author/funder, who has granted medRxiv a license to display the preprint in perpetuity.

It is made available under a CC-BY-NC-ND 4.0 International license .

118. World Health Organization. Health Education: Theoretical Concepts, Effective Strategies and Core Competencies: A Foundation Document to Guide Capacity Development of Health Educators.; 2012.

119. Omarova A, Tussupova K, Hjorth P, Kalishev M, Dosmagambetova R. Water supply challenges in rural areas: A case study from central Kazakhstan. Int J Environ Res Public Health. Published online 2019. doi:10.3390/ijerph16050688

120. Kiyu A, Hardin S. Functioning and utilization of rural water supplies in Sarawak, Malaysia. Bull World Health Organ. Published online 1992.

121. Busienei PJ, Ogendi GM, Mokua MA. Open Defecation Practices in Lodwar, Kenya: A Mixed-Methods Research. Environ Health Insights. Published online 2019. doi:10.1177/1178630219828370

122. Grayson ML, Melvani S, Druce J, et al. Efficacy of Soap and Water and Alcohol $\square$ Based Hand $\square$ Rub Preparations against Live H1N1 Influenza Virus on the Hands of Human Volunteers. Clin Infect Dis. Published online 2009. doi:10.1086/595845

123. Tuladhar E, Hazeleger WC, Koopmans M, Zwietering MH, Duizer E, Beumer RR. Reducing viral contamination from finger pads: Handwashing is more effective than alcohol-based hand disinfectants. J Hosp Infect. Published online 2015. doi:10.1016/j.jhin.2015.02.019

124. Chan EY, Cheng CK, Tam G, Huang Z, Lee P. Knowledge, attitudes, and practices of Hong Kong population towards human A/H7N9 influenza pandemic preparedness, China, 2014 Infectious Disease epidemiology. BMC Public Health. Published online 2015. doi:10.1186/s12889-015-2245-9

125. Hamamura T, Park JH. Regional differences in pathogen prevalence and defensive reactions to the "swine flu" outbreak among East Asians and Westerners. Evol Psychol. Published online 2010. doi:10.1177/147470491000800315

126. Borkow G, Zhou SS, Page T, Gabbay J. A novel anti-influenza copper oxide containing respiratory face mask. PLoS One. Published online 2010. doi:10.1371/journal.pone.0011295

127. Kim K-H, Song D-J, Yu M-H, et al. Hazard Classification of Household Chemical Products in Korea according to the Globally Harmonized System of Classification and labeling of Chemicals. Ann Occup Environ Med. Published online 2013. doi:10.1186/2052-4374-25-11

128. The Government of the Hong Kong Special Administrative Region. CuMask+.

129. Wilder-Smith A, Freedman DO. Isolation, quarantine, social distancing and community containment: Pivotal role for old-style public health measures in the novel coronavirus (2019-nCoV) outbreak. J Travel Med. Published online 2020. doi:10.1093/jtm/taaa020

130. Wong SYS, Kin On K, Chan FKL. What can countries learn from Hong Kong's response to the COVID-19 pandemic? Can Med Assoc J. Published online 2020. doi:10.1503/cmaj.200563

131. Chan KH, Yuen KY. COVID-19 epidemic: disentangling the re-emerging controversy about medical facemasks from an epidemiological perspective. Int J Epidemiol. Published online 2020. doi:10.1093/ije/dyaa044

132. Servick K. Would everyone wearing face masks help us slow the pandemic? Science (80). Published online 2020. doi:10.1126/science.abb9371

133. Zhang H, Shaw R. Identifying Research Trends and Gaps in the Context of COVID-19. Int. J. Environ. Res. Public Health. Published online 2020. doi:10.3390/ijerph17103370 